\title{
Cortico-Basal Ganglia Reward Network: Microcircuitry
}

\author{
Susan R Sesack ${ }^{\star, 1,2}$ and Anthony A Grace ${ }^{\star, 1,2}$ \\ ${ }^{1}$ Department of Neuroscience, University of Pittsburgh, Pittsburgh, PA, USA; ${ }^{2}$ Department of Psychiatry, University of \\ Pittsburgh, Pittsburgh, PA, USA
}

\begin{abstract}
Many of the brain's reward systems converge on the nucleus accumbens, a region richly innervated by excitatory, inhibitory, and modulatory afferents representing the circuitry necessary for selecting adaptive motivated behaviors. The ventral subiculum of the hippocampus provides contextual and spatial information, the basolateral amygdala conveys affective influence, and the prefrontal cortex provides an integrative impact on goal-directed behavior. The balance of these afferents is under the modulatory influence of dopamine neurons in the ventral tegmental area. This midbrain region receives its own complex mix of excitatory and inhibitory inputs, some of which have only recently been identified. Such afferent regulation positions the dopamine system to bias goal-directed behavior based on internal drives and environmental contingencies. Conditions that result in reward promote phasic dopamine release, which serves to maintain ongoing behavior by selectively potentiating ventral subicular drive to the accumbens. Behaviors that fail to produce an expected reward decrease dopamine transmission, which favors prefrontal cortical-driven switching to new behavioral strategies. As such, the limbic reward system is designed to optimize action plans for maximizing reward outcomes. This system can be commandeered by drugs of abuse or psychiatric disorders, resulting in inappropriate behaviors that sustain failed reward strategies. A fuller appreciation of the circuitry interconnecting the nucleus accumbens and ventral tegmental area should serve to advance discovery of new treatment options for these conditions.

Neuropsychopharmacology Reviews (2010) 35, 27-47; doi: I0.1038/npp.2009.93; published online 12 August 2009
\end{abstract}

Keywords: accumbens; dopamine; prefrontal cortex; ventral tegmental area; glutamate; GABA

\section{INTRODUCTION}

The neurotransmitter dopamine (DA) is released from neurons in the midbrain ventral tegmental area (VTA) that have widespread projections to regions known to be involved in reward processes and in guiding goal-directed behavior (Wise, 2004; Grace et al, 2007; Ikemoto, 2007). One area of the brain in which many of these systems converge is the nucleus accumbens (NAc). The NAc has a central role in the integration of cortical afferent systems under the modulatory influence of DA. In turn, the NAc and many of its inputs are also involved in directly or indirectly regulating DA neuron activity states. By examining the afferent drive of the NAc, its modulation by DA, and the afferent regulation of VTA DA cells, this article attempts to draw a functional circuit that illustrates the function of

${ }^{*}$ Correspondence: Dr SR Sesack or Dr AA Grace, Department of Neuroscience, University of Pittsburgh, Langley Hall, Room 210, Pittsburgh, PA 15260, USA, Tel: +1 4126245158 (SR Sesack) or + 1 4126244609 (AA Grace), Fax: +1 412624 9198,

E-mail: sesack@pitt.edu or graceaa@pitt.edu

Received 30 April 2009; revised 16 June 2009; accepted 1 July 2009 these two major structures in modulating behavioral responses that serve reward acquisition.

\section{NUCLEUS ACCUMBENS}

\section{Connectivity}

The NAc is part of the ventral striatal complex and serves as a critical region where motivations derived from limbic regions interface with motor control circuitry to regulate appropriate goal-directed behavior (Mogenson et al, 1980; Groenewegen et al, 1996; Nicola et al, 2000; Zahm, 2000; Wise, 2004). Like other parts of the striatal complex, the NAc receives extensive excitatory afferents from the cerebral cortex and thalamus. It projects to the ventral pallidum (VP), which innervates the mediodorsal and other thalamic divisions, thus completing cortico-striato-pallidal-thalamocortical loops (Zahm and Brog, 1992; O’Donnell et al, 1997). Together these structures form essential components of the circuitry that serves to optimize the behavioral response to rewards and conditioned associations. Alterations of synaptic transmission within various elements of this circuitry are strongly implicated in the 
development of addictive disorders (Kalivas et al, 2005; Robbins et al, 2008; Carlezon and Thomas, 2009).

Divisions. The NAc is divided into two major territories: the core is the central portion directly beneath and continuous with the dorsal striatum and surrounding the anterior commissure, and the shell occupies the most ventral and medial portions of the NAc. A third rostral pole division has also been identified (Zahm and Brog, 1992; Zahm and Heimer, 1993; Jongen-Rêlo et al, 1994). The NAc core and shell districts share striatal characteristics, in that approximately $90 \%$ of the cells are typical medium spiny projection neurons (Meredith, 1999). The remainder are local circuit interneurons, including cholinergic and parvalbumin cells (Kawaguchi et al, 1995). The NAc core and shell differ in their precise cellular morphology, neurochemistry, projection patterns, and functions (Heimer et al, 1991; Meredith et al, 1992; Zahm and Brog, 1992; Zahm and Heimer, 1993; Jongen-Rêlo et al, 1994; Meredith et al, 1996; Usuda et al, 1998; Meredith, 1999). The shell division, and particularly its medial aspect, is often more prominently associated with drug reward (Carlezon et al, 1995; Rodd-Henricks et al, 2002; Sellings and Clarke, 2003; Ikemoto, 2007), although the core also contributes to motivated behaviors that are cue-conditioned, including drug-seeking (Kalivas and McFarland, 2003; Robbins et al, 2008).

Superimposed on the core and shell subterritories of the NAc are compartments that at least partly resemble the patch and matrix organization of the dorsal striatum, the latter being based on the laminar patterns of cortical afferents and multiple specific biochemical markers (Gerfen, 1992). For the NAc, a simple patch-matrix organization has been difficult to define, and most authors agree that the compartmental segregation of cells and input-output channels in this region is highly complex (Voorn et al, 1989; Martin et al, 1991; Zahm and Brog, 1992; Jongen-Rêlo et al, 1993; Meredith et al, 1996; van Dongen et al, 2008).

Afferents: excitatory. Multiple limbic associated areas provide the excitatory cortical innervation to the NAc (Figure 1), including medial and lateral divisions of the prefrontal cortex (PFC), entorhinal cortex and ventral subiculum of the hippocampus (vSub), and basolateral amygdala (BLA) (Kelley and Domesick, 1982; Kelley et al, 1982; Groenewegen et al, 1987; Kita and Kitai, 1990; McDonald, 1991; Berendse et al, 1992; Brog et al, 1993; Totterdell and Meredith, 1997; Reynolds and Zahm, 2005). The NAc shell is innervated primarily by ventral portions of the prelimbic, infralimbic, medial orbital, and ventral agranular insular cortices, whereas the core receives input mainly from dorsal parts of the prelimbic cortex and dorsal agranular insular areas (Berendse et al, 1992; Brog et al, 1993). The vSub projects caudomedially with a preference for the NAc shell, whereas the dorsal subiculum projects to more rostrolateral regions including the core (Groenewegen et al, 1987; Brog et al, 1993). The BLA generates a complex rostral to core and caudal to shell topography that also varies according to patch-matrix compartments in the NAc (Wright et al, 1996).

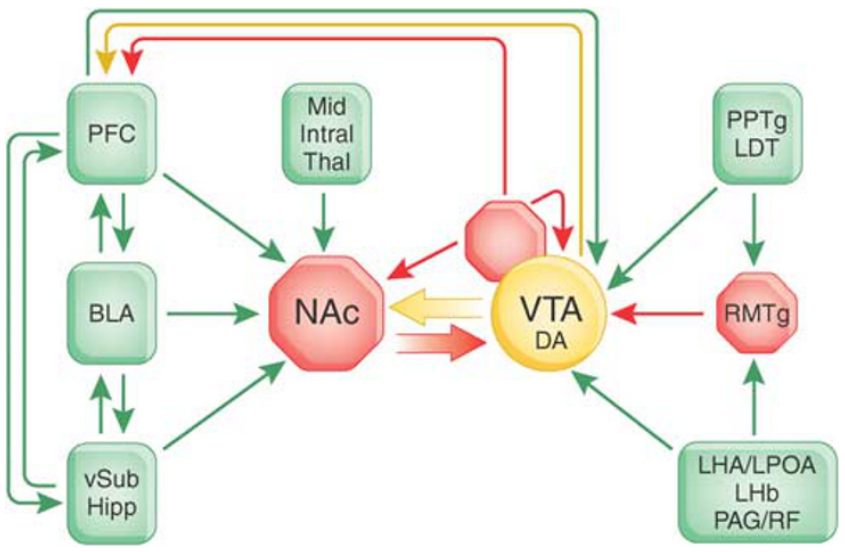

Figure 1. Principal afferents linking brain centers for goal-directed behavior with the NAc and VTA. For clarity, only some of the projections are shown, and the principal efferent pathways from the NAc are illustrated in Figure 2. Red indicates inhibitory structures and pathways, green excitatory connections, and yellow the modulatory influence of DA. Please refer to the text for detailed explanation. BLA, basolateral amygdala; LHA/LPOA, lateral hypothalamic and lateral preoptic areas; $\mathrm{LHb}$, lateral habenula; Mid/Intral Thal, midline and intralaminar thalamic nuclei; NAc, nucleus accumbens; PAG/RF, periaqueductal gray and reticular formation; PFC, prefrontal cortex; PPTg/LDT, pedunculopontine and laterodorsal tegmentum; RMTg, mesopontine rostromedial tegmental nucleus; VP, ventral pallidum; vSub/Hipp, ventral subiculum of the hippocampus; VTA, ventral tegmental area.

Cortical neurons are the likely promoters of goal-directed behaviors, with the vSub providing spatial and contextual information, the PFC supplying executive control, including task switching and response inhibition, and the BLA communicating information regarding conditioned associations as well as affective drive (Moore et al, 1999; Wolf, 2002; Kalivas et al, 2005; Ambroggi et al, 2008; Ishikawa et al, 2008; Ito et al, 2008; Gruber et al, 2009a; Simmons and Neill, 2009). The NAc provides a crucial site for convergence of these various behavioral drives, although the relevant cortical structures also maintain interconnections with each other (Figure 1; Swanson and Köhler, 1986; Sesack et al, 1989; Jay et al, 1992; Brinley-Reed et al, 1995; Bacon et al, 1996; Pitkänen et al, 2000).

Thalamic afferents to the ventral striatum arise from midline and intralaminar nuclei (Figure 1), including the paraventricular, paratenial, intermediodorsal, central medial, rhomboid, reunions, and rostral parafascicular nuclei (Kelley and Stinus, 1984; Berendse and Groenewegen, 1990; Smith et al, 2004). In the rat and primate, the NAc core is innervated primarily by the intermediodorsal, the shell by the paraventricular, and the rostral pole by the paratenial nucleus (Berendse and Groenewegen, 1990; Smith et al, 2004). Some thalamic neurons innervating the NAc send collateral projections to the PFC (Otake and Nakamura, 1998). The functions of thalamostriatal projections are less well studied compared to corticostriatal pathways. Nevertheless, the former are likely to operate in arousal and directing attention to behaviorally significant events (Smith et al, 2004). 
Afferents: inhibitory/modulatory. There are few strong inhibitory afferents to the NAc, although there are reciprocal GABA projections from the VP, other parts of the basal forebrain, and the VTA (Brog et al, 1993; Groenewegen et al, 1993; Churchill and Kalivas, 1994; Van Bockstaele and Pickel, 1995; Wu et al, 1996). The shell of the NAc also receives a projection from orexin (hypocretin) neurons in the lateral hypothalamus (Peyron et al, 1998). Although this peptide is often reported to be excitatory, it appears to have inhibitory actions on NAc neurons (Martin et al, 2002). Additional peptidecontaining projections from the lateral hypothalamus express melanin-concentrating hormone (Bittencourt et al, 1992).

The NAc also receives modulatory afferents from the brainstem, including DA and GABA projections from the medial substantia nigra zona compacta $(\mathrm{SNc})$ and VTA (Figure 1; see 'Efferents' in section Ventral tegmental area) (Voorn et al, 1986; Van Bockstaele and Pickel, 1995; Ikemoto, 2007). The DA innervation forms an essential component of reward circuitry and is recruited by both natural rewards and psychostimulants (Koob, 1992; Wise, 2004; Ikemoto, 2007). The NAc also receives serotonin and non-serotonin inputs from the dorsal raphe nucleus (Van Bockstaele and Pickel, 1993; Brown and Molliver, 2000). There is a small norepinephrine projection from the locus coeruleus (LC) and nucleus of the solitary tract directed mainly to the NAc shell (Swanson and Hartman, 1975; Brog et al, 1993; Delfs et al, 1998) and additional sparse afferents from other brainstem regions, including the pedunculopontine tegmentum (PPTg), parabrachial nucleus, and periaqueductal gray (Brog et al, 1993).

Microcircuitry. Excitatory cortical afferents to the NAc typically synapse onto the spines of medium spiny neurons. Fewer synapse onto the dendrites of local circuit interneurons with preference for parvalbumin-containing GABA cells vs cholinergic neurons (Totterdell and Smith, 1989; Kita and Kitai, 1990; Meredith and Wouterlood, 1990; Meredith et al, 1990; Sesack and Pickel, 1990; Lapper and Bolam, 1992; Lapper et al, 1992; Sesack and Pickel, 1992b; Bennett and Bolam, 1994; Johnson et al, 1994; Totterdell and Meredith, 1997; Thomas et al, 2000; French and Totterdell, 2004; Smith et al, 2004; French et al, 2005). An important series of studies by French and Totterdell established that multiple sources of cortical innervation converge onto individual medium spiny neurons in the NAc. This was shown for PFC and vSub inputs as well as for BLA and vSub projections (French and Totterdell, 2002, 2003). The fact that both PFC and BLA afferents converge with $\mathrm{vSub}$ projections suggests that convergence is also likely to occur for PFC and BLA inputs to at least some medium spiny neurons, given the high degree of co-convergence reported. Physiological evidence also supports convergence of cortical inputs to medium spiny neurons, permitting temporal integration of excitatory drive (O'Donnell and Grace, 1995; Finch, 1996; McGinty and Grace, 2009) (see section Interaction between hippocampal and prefrontal inputs). It is possible that varying degrees of afferent convergence within the ventral striatum give rise to relatively segregated input-output channels that form functional ensembles (Pennartz et al, 1994; Groenewegen et al, 1999).

Accumulating evidence suggests that midline and rostral intralaminar thalamic structures synapse mainly onto dendritic spines in a manner similar to corticostriatal inputs, whereas caudal intralaminar thalamic nuclei more commonly contact the dendritic shafts of striatal and NAc neurons, including interneurons (Dubé et al, 1988; Meredith and Wouterlood, 1990; Lapper and Bolam, 1992; Sidibé and Smith, 1999; Smith et al, 2004).

Dopamine afferents to the NAc synapse onto GABA neurons (Pickel et al, 1988) with medium spiny morphology (Pickel and Chan, 1990; Smith et al, 1999). Whether DA axons also synapse onto local circuit neurons in the NAc has not been thoroughly investigated. There is one report of DA synapses onto the class of interneurons containing nitric oxide synthase (Hidaka and Totterdell, 2001). Careful ultrastructural analysis in the dorsal striatum has failed to reveal DA synaptic input to cholinergic cells (Pickel and Chan, 1990), which nevertheless express high levels of D2 receptors (Alcantara et al, 2003) and therefore respond to tonic DA levels in the extrasynaptic space (Wang et al, 2006).

For medium spiny neurons, the dendritic spines that receive excitatory synapses from cortical axon terminals sometimes also display inhibitory or modulatory-type synapses from DA axons. This has been demonstrated in the NAc for all three cortical afferent sources (Totterdell and Smith, 1989; Sesack and Pickel, 1990, 1992b; Johnson et al, 1994) in a manner similar to cortical projections to more dorsal striatal regions (Bouyer et al, 1984; Smith et al, 1994). The extent of this convergence is likely to be greater in the core than in the shell division (Zahm, 1992), given the less extensive dendritic trees of shell neurons (Meredith et al, 1992).

In the rat, convergence of DA and thalamostriatal projections has also been reported for the midline paraventricular innervation to the NAc shell (Pinto et al, 2003) and for presumed thalamostriatal projections labeled for the vesicular glutamate transporter type 2 (VGlut2) (Moss and Bolam, 2008). In the dorsal striatum of monkeys, caudal intralaminar thalamic afferents reportedly do not converge synaptically with DA axons onto common dendritic spines. However, this is likely to reflect the more proximal placement of synapses from this particular thalamic division (Smith et al, 1994, 2004).

The so-called triad of elements: spine, glutamate synapse, and DA synapse, creates the potential for DA to modulate discretely specific sources of glutamate transmission onto distal dendritic compartments as opposed to a more generalized effect on overall cell excitability. This structural configuration also enables presynaptic interactions between DA and glutamate by limiting the diffusion distance necessary for each transmitter to reach extrasynaptic receptors on the apposing nerve terminal (Moss and Bolam, 2008; Yao et al, 2008; Sesack, 2009). 
On the other hand, dual synaptic convergence onto common spines is probably a relatively infrequent occurrence in the NAc, based on estimates of the dorsal striatum where they account for less than $10 \%$ of spines (Wilson et al, 1983). Moreover, not all of the spines that receive dual input may be innervated by DA axons. These observations suggest that the synapses of DA axons onto distal dendritic shafts, as opposed to spines (Pickel and Chan, 1990; Zahm, 1992), are also important for modulating discrete sources of glutamate transmission.

In contradiction to arguments favoring selective modulation of particular glutamate afferents, recent quantitative analyses suggest that DA axons in the striatum (and possibly by extension the NAc) are arranged to form a lattice network such that all parts of this region are within one micron of a DA synapse (Moss and Bolam, 2008). The importance of this suggestion is highlighted by reports that (1) DA receptors are predominantly extrasynaptic (Dumartin et al, 1998; Yao et al, 2008; Sesack, 2009), (2) DA communicates through volume transmission in addition to a synaptic mode (Descarries et al, 1996; Moss and Bolam, 2008), and (3) DA modulates the general excitability of striatal and NAc neurons (O'Donnell and Grace, 1996; Nicola et al, 2000; Surmeier et al, 2007).

Physiological data strongly support DA alterations of responses evoked by cortical afferents to NAc medium spiny neurons (Yang and Mogenson, 1984; O'Donnell and Grace, 1994; Nicola et al, 2000; Charara and Grace, 2003; O'Donnell, 2003; Brady and O'Donnell, 2004; Goto and Grace, 2005b) (see section Regulation of NAc activity and its role in reward). As discussed above, such modulatory actions may reflect specific synaptic or more generalized extrasynaptic effects. Nevertheless, the close convergence of DA and glutamate synapses onto spines or distal dendrites provides a potential substrate for enabling local plasticity of glutamate transmission based on synaptic experience (Flores et al, 2005; Day et al, 2006; Surmeier et al, 2007) or chronic exposure to psychostimulants that enhance DA levels (Robinson and Kolb, 2004; Wolf et al, 2004; Lee et al, 2006).

Based on information from studies of either dorsal or ventral striatum, medium spiny neurons appear to provide only weak inhibition of each other (Taverna et al, 2004; Tepper et al, 2008). However, a potential excitatory influence has been reported in the dorsal striatum based on peptide-induced facilitation of glutamatergic drive (Blomeley et al, 2009). Medium spiny neurons are more strongly and reciprocally connected to local circuit neurons (Izzo and Bolam, 1988; Pickel and Chan, 1990; Martone et al, 1992; Bennett and Bolam, 1994; Kawaguchi et al, 1995; Hussain et al, 1996; Taverna et al, 2007; Tepper et al, 2008), which are also interconnected with each other in the NAc (Hussain et al, 1996) and dorsal striatum (Kawaguchi et al, 1995). The innervation of local circuit neurons by cortical afferents to the striatum and NAc (see above) provides circuitry for feedforward inhibition of medium spiny cells.
As shown in vitro or in anesthetized rats, this inhibition is powerful and influences multiple medium spiny neurons (Mallet et al, 2005; Tepper et al, 2008; Gruber et al, 2009b). However, during behavioral tasks in awake animals, the activity patterns of presumed striatal interneurons are highly variable and independent, suggesting that they contribute mainly to the specific details of striatal processing rather than the global coordination of firing (Berke, 2008).

Efferents. The major projections of the NAc are to the VP, substantia nigra, VTA, hypothalamus, and brainstem (Figure 2; Haber et al, 1990; Zahm and Heimer, 1990; Heimer et al, 1991; Usuda et al, 1998; Nicola et al, 2000; Zahm, 2000; Dallvechia-Adams et al, 2001). The NAc core projects primarily to the dorsolateral portion of the VP, the entopeduncular nucleus, and the substantia nigra zona reticulata $(\mathrm{SNr})$. The shell mainly innervates the ventromedial VP division, substantia innominata, lateral hypothalamic area, lateral preoptic area, SNc, VTA, periaqueductal gray, parabrachial nucleus, and PPTg (Haber et al, 1990; Zahm and Heimer, 1990; Heimer et al, 1991; Usuda et al, 1998). The VP territories also project to some of the same targets, with the dorsolateral VP innervating mainly the $\mathrm{SNr}$ and subthalamic nucleus and the ventromedial VP projecting to the VTA, basal forebrain, and preoptic areas (Zahm, 1989; Zahm and Heimer, 1990). It should also be noted that projections of the NAc shell to the VTA influence DA cells that in turn project to the NAc core, creating a medial to lateral series of spiraling projections that allow limbic associated structures to influence transmission in successively more motor-related parts of basal ganglia circuitry. Evidence for this looped medial to lateral organization was first described in rats by Nauta in 1978 (Nauta et al, 1978) and later verified by others in rats and cats (Somogyi et al, 1981; Groenewegen and Russchen, 1984; Heimer et al, 1991; Zahm and Heimer, 1993). In the primate, where the functional subdivisions of the striatum are most discrete, the spiraling organization of striatonigral-striatal

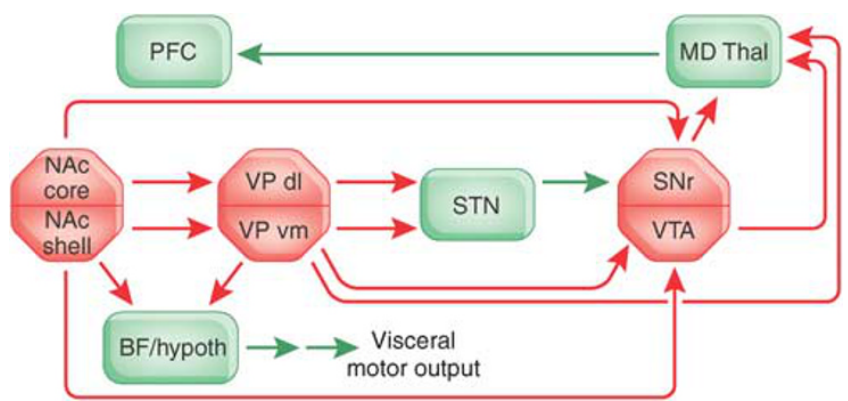

Figure 2. Hypothetical direct and indirect output pathways whereby the NAc core and shell may disinhibit or inhibit, respectively, adaptive motor pathways for maximizing reward acquisition. Only major projections are shown. Red indicates inhibitory structures and pathways, whereas green indicates excitatory connections. Please refer 'Efferents' in section Nucleus Accumbens for detailed explanation. BF Hypoth, basal forebrain and hypothalamus; MD Thal, mediodorsal thalamic nucleus; NAc, nucleus accumbens; PFC, prefrontal cortex; SNr, substantia nigra zona reticulata; STN, subthalamic nucleus; VP dl/vm, ventral pallidum, dorsolateral, and ventromedial; VTA, ventral tegmental area. 
projections appears most refined and has been most thoroughly characterized (Haber et al, 2000).

Among the various outputs of the NAc and VP, a subset can be viewed as functionally analogous to the direct and indirect pathways that are involved in behavioral activation and response inhibition (Figure 2; Alexander et al, 1990). This organization is more striatal-like for the core than the shell division (Zahm, 1989; Zahm and Brog, 1992; Nicola et al, 2000). The direct pathway from the NAc core involves mainly projections to the SNr (Montaron et al, 1996) and from there to the mediodorsal thalamus. The dorsolateral $\mathrm{VP}$, which is also targeted by the NAc core, appears to have only minor projections to the mediodorsal thalamus (Zahm et al, 1996; O’Donnell et al, 1997) but nevertheless mediates some direct actions on thalamic activity (Lavin and Grace, 1994). By the direct route, cortical activation of NAc neurons leads ultimately to disinhibition of appropriate action plans that facilitate reward acquisition. The indirect circuit travels through the dorsolateral VP and subthalamic nucleus before reaching the $\mathrm{SNr}$ (Figure 2). Cortical activation of this circuit is likely to inhibit motor plans that are maladaptive, either for obtaining reward or for avoiding punishment (Mink, 1996; Redgrave et al, 1999).

A simple division of NAc shell neurons into direct and indirect pathways is complicated by the fact that the shell is really a hybrid structure: part basal ganglia and part limbic region (Zahm, 1989; Zahm and Heimer, 1990; Heimer et al, 1991; Zahm and Brog, 1992). In addition to being a ventral extension of the striatum, with striatal cell types and inputoutput connections, the shell is also part of the extended amygdala complex with projections to hypothalamic and brainstem structures important for visceral motor control and affect (Alheid and Heimer, 1988; Waraczynski, 2006).

Despite these difficulties, some theories regarding direct and indirect pathways involving the NAc shell have been put forward (Figure 2). For example, it has been suggested that both direct and indirect projections might involve the ventromedial VP (Nicola et al, 2000), with the direct circuit contacting cells that project to the mediodorsal thalamus (O'Donnell et al, 1997) and the indirect projections involving VP neurons that subsequently project to the subthalamic nucleus. Alternatively, parts of the basal forebrain and hypothalamus may serve the role of output structures for visceral motor functions, with projections to them arising directly from the NAc (and producing inhibition) or indirectly through the VP (and ultimately producing disinhibition) (Nicola et al, 2000). However, the fact that these targets have only minor projections to primarily nonspecific thalamic nuclei strains comparisons to more dorsal parts of basal ganglia circuitry (Heimer et al, 1991; O’Donnell et al, 1997; Zahm, 2006).

A third possibility is that the direct and indirect pathways from the NAc shell converge on the VTA, which may act as a basal ganglia output structure via projections to the mediodorsal thalamus. The direct pathway would proceed from the NAc to the VTA, whereas the indirect route would first involve the connection to the ventromedial VP and then its projections to the VTA. Although VTA DA neurons project only weakly to the thalamus in the rat (Groenewegen, 1988), they provide extensive innervation of midline thalamic structures in the monkey (Sánchez-González et al, 2005; Melchitzky et al, 2006). Moreover, non-DA cells appear to participate in these projections in both rats and primates (Sánchez-González et al, 2005; Melchitzky et al, 2006; Del-Fava et al, 2007). Although not yet directly tested, it is likely that many of these are GABA VTA neurons serving as traditional basal ganglia output cells.

In the dorsal striatum, the direct and indirect output pathways are also distinguished by the expression of different DA receptor subtypes, with D1 receptors being the dominant subclass in direct pathway striatal neurons and D2 receptors expressed principally by indirect pathway cells (Gerfen et al, 1990; Surmeier et al, 2007; Sesack, 2009). This distinction is most evident in anatomical studies (Hersch et al, 1995; Le Moine and Bloch, 1995; Deng et al, 2006), whereas electrophysiological recordings tend to report cells responding to selective agonists for both receptors (Uchimura et al, 1986; Surmeier et al, 1992; Cepeda et al, 1993). Aspects of this controversy have been resolved by the finding that many striatal medium spiny neurons have the capacity to express mixed receptor subtypes from the extended D1 (D1 or D5) and D2 (D2, D3, or D4) families (Surmeier et al, 1996) and by the discovery that complex indirect mechanisms can explain some instances of apparent physiological coexpression of D1 and D2 receptors (Wang et al, 2006; Surmeier et al, 2007).

Different populations of NAc medium spiny neurons also appear to express D1 or D2 receptors selectively (Le Moine and Bloch, 1996; Lee et al, 2006), although this segregation is less complete as compared to the dorsal striatum. Moreover, the greater overall expression of DA D3 receptors in NAc neurons (Le Moine and Bloch, 1996) indicates a greater likelihood of mixed physiological response patterns (Uchimura et al, 1986) in this region. In general, D2 receptors are expressed mainly in NAc neurons that project to the VP and rarely in those that innervate the midbrain, whereas D1 receptors are expressed in both cell populations (Robertson and Jian, 1995; Lu et al, 1997, 1998).

\section{Regulation of NAc Activity and its Role in Reward}

Modulation by DA. Dopamine exerts multiple and complex effects on neurons within the striatal complex. DA acting on D2 receptors potently inhibits NAc neurons (White and Wang, 1986; Lin et al, 1996; O'Donnell and Grace, 1996). In contrast, D1 receptor stimulation potentiates glutamatergic drive (Cepeda et al, 1998; Chergui and Lacey, 1999; West and Grace, 2002). Confirmatory data derive from examining the effects of locally applied antagonists in vivo, such that D2 antagonists increase NAc neuron firing and D1 antagonists decrease cell excitability (West and Grace, 2002). Moreover, studies have shown that DA potently modulates gap junction interactions among NAc neurons by increasing synchrony among neurons (Onn and Grace, 
1994; Onn et al, 2000). Such an effect is likely to be particularly effective in the lateral transmission of slow membrane voltage changes, such as those occurring during NAc neuron 'up' states (O'Donnell and Grace, 1995). Therefore, DA has multifaceted effects in both altering NAc neuronal activity and modulating the balance of afferent inputs and their integration, presumably in a manner that most effectively shapes goal-directed behavior.

Ventral subiculum inputs. Neurons within the NAc when recorded in vivo are known to exhibit up-down states (O'Donnell and Grace, 1995). The up states appear to function as a gating mechanism, in that neurons only discharge action potentials from the depolarized up state. The up states are driven by afferent input from the vSub of the hippocampus (O'Donnell and Grace, 1995). The vSub is well positioned to provide such a modulatory gating influence. The vSub receives afferent inputs from a number of regions related to (1) affect, eg the amygdala and LC (Oleskevich et al, 1989; Schroeter et al, 2000; French et al, 2003); (2) spatial location, eg dorsal hippocampus/CA1 (Amaral et al, 1991); and (3) higher cognitive functions, eg indirect inputs from the PFC (O'Mara, 2005). The vSub itself is involved in the central regulation of stress (Herman and Mueller, 2006) and in context-dependent behaviors (Jarrard, 1995; Maren, 1999; Sharp, 1999; Fanselow, 2000). Thus, by integrating spatial and affective information, the vSub is positioned to provide information regarding the affective valence of locations in space, which would be critical in evaluating context-dependent processes. Indeed, several events in which context is important, such as contextdependent fear conditioning (Fanselow, 2000; Maren and Quirk, 2004), the behavioral responses to stress (Bouton and Bolles, 1979; Bouton and King, 1983), or amphetamine sensitization (Vezina et al, 1989; Badiani et al, 2000; Crombag et al, 2000), are disrupted by inactivation of the vSub (Lodge and Grace, 2008; Valenti and Grace, 2008).

The vSub drive of NAc neurons is potently modulated by the DA system. In particular, D1 agonists increase vSub drive of NAc neurons. This is likely because of an effect on the NAc neuron itself rather than a presynaptic action, given the results of paired-pulse experiments (Goto and Grace, 2005b) and the lack of presynaptic D1 receptors within the striatum (Hersch et al, 1995). This afferent modulation is affected primarily by phasic DA release (Grace, 1991; Goto and Grace, 2005b) driven by DA neuron burst firing (Grace, 1991). Given that DA neurons emit phasic bursts of spikes when exposed to stimuli signaling a rewarding event (Schultz, 1998b), the ability of bursts to potentiate vSub-NAc transmission is expected to be involved in selecting reward-related behavior. The DA input does indeed affect the vSub-NAc projection in a behaviorally salient manner. Thus, when the vSub is disconnected from the NAc by unilaterally inactivating the vSub and injecting a D1 antagonist into the contralateral NAc, there is a disruption in the acquisition of learned behavior in the rat (Goto and Grace, 2005b). In addition to DA modulation, the vSub input is also disrupted by psychotomimetic drugs such as phencyclidine. Administration of behaviorally effective doses of phencyclidine potently attenuates vSub-driven up states in NAc neurons (O'Donnell and Grace, 1998).

The drive of the NAc by the vSub also exhibits plasticity in response to repeated activation. Thus, tetanic stimulation of the vSub leads to long-term potentiation (LTP) within the vSub-NAc pathway. This is also dependent on D1 receptor stimulation, given that blockade of D1 receptors prevents the induction of LTP (Goto and Grace, 2005a). Moreover, LTP induction is NMDA dependent (Goto and Grace, 2005a).

Prefrontal cortical inputs. The medial prefrontal cortex (mPFC) also has glutamatergic inputs to the NAc. However, its impact is strongly dependent on the timing of its activation. Brief stimulation of the $\mathrm{mPFC}$ produces an excitatory potential within the NAc (O'Donnell and Grace, 1993, 1994); moreover, this mPFC input is potently and selectively attenuated by $\mathrm{D} 2$ receptor stimulation that acts presynaptically on mPFC terminals (O'Donnell and Grace, 1994; West et al, 2002). This D2 receptor stimulation is promoted primarily by tonic DA levels within the NAc that in turn are dependent on DA neuron population activity (Floresco et al, 2003; Goto and Grace, 2005b). In contrast to the vSub input, disconnection of the mPFC from the NAc (by unilateral inactivation of the $\mathrm{MPFC}$ and stimulation of D2 receptors in the contralateral NAc) does not interfere with learning a task, which is presumably more dependent on the vSub-NAc pathway. However, such disconnection does interfere with switching strategies (Goto and Grace, 2005b). In contrast, using paired-pulse stimulation, it is clear that activation of the mPFC also induces a subsequent inhibitory potential that decreases NAc neuronal excitability (O'Donnell and Grace, 1993).

Tetanic stimulation of the MPFC also induces LTP within the mPFC-NAc pathway; although the characteristics of the LTP are different from those evoked by vSub stimulation. Specifically, in addition to being attenuated by D2 stimulation, the induction of LTP in the MPFC-NAc pathway is not dependent on NMDA receptors (Goto and Grace, 2005a).

Amygdala inputs. The BLA comprises the third major input to the NAc. The amygdala is a region involved in expression of emotion and in learned emotional behaviors (LeDoux, 2000). This afferent is also glutamatergic in nature (O'Donnell and Grace, 1995; Charara and Grace, 2003; French and Totterdell, 2003) and produces a long latency, long duration excitation within the NAc (O'Donnell and Grace, 1995) that is modulated by D1 receptors (Charara and Grace, 2003). The BLA also has potent interactions with other components of the limbic system. For example, it provides strong excitatory drive to the vSub (Lipski and Grace, 2008) and to the mPFC. The BLA-mPFC projection is important in affective conditioning processes (Laviolette and Grace, 2006). Thus, neurons in the mPFC that are excited by the BLA exhibit potent excitation by stimuli associated with aversive events (Laviolette et al, 2005; McGinty and Grace, 2008). Moreover, this response depends on an intact DA input to the mPFC (Laviolette et al, 2005). In turn, the mPFC provides a powerful attenuation of BLA activation by sensory stimuli as shown both 
electrophysiologically (Rosenkranz and Grace, 2001, 2002) and in human imaging studies (Hariri et al, 2003). Thus, both the recognition of salience and the learned response to affective stimuli depend on the BLA-mPFC interaction.

Interaction between hippocampal and prefrontal inputs. The synaptic convergence of vSub, BLA, and MPFC inputs onto the same sets of NAc neurons (O'Donnell and Grace, 1995; French and Totterdell, 2002, 2003), and their common modulation by DA, provides strong evidence that the NAc serves as a crossroads for integration of information about environmental context and affect with higher cognitive processes. Moreover, the vSub and the mPFC exhibit complex interactions within the NAc that impact goal-directed behavior. The nature of these interactions is strongly dependent on the timing of the inputs. Thus, vSub stimulation potently promotes NAc neuron firing both by evoking EPSPs and by inducing up states (O'Donnell and Grace, 1995). However, the ability of the vSub to promote the NAc is apparently dependent on more than the direct vSub-NAc projection. The vSub also projects to the mPFC, which, in turn, projects to the NAc. If the mPFC is inactivated, there is a strong attenuation of the ability of the vSub to drive the NAc (Belujon and Grace, 2008). On the other hand, if the vSub-NAc pathway is stimulated at high frequency, facilitation by the $\mathrm{mPFC}$ is no longer required. Thus, the mPFC provides a 'permissive' role in vSub-NAc drive and synaptic plasticity. Alternately, if the mPFC is stimulated first, it will attenuate the vSub drive by activation of local inhibitory circuits (O'Donnell and Grace, 1993; Goto and O'Donnell, 2002). Therefore, if the input from the vSub arrives first, the mPFC will facilitate this drive; however, if the mPFC is first activated, the vSub afferent input is attenuated.

The vSub and the NAc also exhibit dynamic interactions with respect to activation history. As reviewed above, highfrequency stimulation of either the vSub or the MPFC will induce LTP in the respective pathways. However, the vSub and $\mathrm{mPFC}$ also exhibit competition between these afferent systems. Thus, high-frequency stimulation of the vSub will not only induce LTP in the vSub-NAc pathway but will also induce long-term depression (LTD) in the mPFC-NAc pathway. Subsequent high-frequency stimulation of the MPFC reverses this condition, causing induction of LTP in the MPFC-NAc pathway while producing LTD in the vSubNAc pathway. Therefore, activation of one afferent system will attenuate afferent drive from the alternate system (Goto and Grace, 2005a). This balance is further modulated by DA, with increases in DA favoring the vSub-NAc pathway and decreases in DA favoring the mPFC-NAc pathway. Such a condition could have important implications with respect to reward-related behaviors.

As reviewed above, the vSub-NAc pathway is proposed to maintain responding on a learned task, whereas the mPFC-NAc pathway facilitates switching to novel response strategies. It has been shown that behaviors that lead to reinforcement are associated with activation of DA neuron firing (Schultz, 1998b). Thus, a reinforced behavior would lead to DA release, followed by D1 receptor-mediated potentiation of vSub-NAc drive to reinforce ongoing behavior. At the same time, DA release would produce a D2 receptor-mediated attenuation of mPFC-NAc drive and so reduce mPFC-mediated task switching. Conversely, when the response strategy becomes ineffective, there would be a drop in DA neuron activity (Hollerman and Schultz, 1998; Schultz and Dickinson, 2000). Such a decrease in DA transmission would then be predicted to attenuate vSubmediated drive of ongoing behavior while disinhibiting mPFC-mediated behavioral flexibility. This would be expected to cause the animal to switch from their current, ineffective behavioral strategy and test new strategies. Once a new strategy is found to be effective, the subsequent reinforcement-driven activation of the DA system would strengthen the new behavior by attenuating the mPFC input and facilitating vSub maintenance of activity (Goto and Grace, 2008).

Role of the dorsal striatum in reward learning. Studies have demonstrated a role for DA in the ventral striatum in the acquisition and in the expression of appetitive responses and motivation (Montague et al, 2004). There is increasing evidence that the dorsal striatum is important in rewardrelated processes. In particular, studies have suggested that the dorsal striatum is involved in instrumental behavior and in habit formation. Thus, the initial reinforcement of appetitive and drug stimuli activates ventral striatal structures (Bonson et al, 2002; Yin et al, 2008); however, with repetitive exposure, activation of more dorsal striatal structures will predominate (Robbins and Everitt, 2002; Yin et al, 2008). This transition from reinforcement to habit formation is believed to be under frontal cortical control (Berke, 2003) and enables an animal to exert cognitive influence over adaptive decision-making. Thus, with repeated exposure to drugs of abuse, there is progressive activation of more dorsal striatal areas (Porrino et al, 2004; Saka et al, 2004), and this transition is accompanied by a similar shift in DA release (Ito et al, 2002; Wong et al, 2006). Such a transition can be facilitated by the interconnected loops of the DA-striatal system, in which limbic activation affects progressively more cognitive and motor regions of the striatal loop (see 'Efferents' in section Nucleus accumbens).

\section{VENTRAL TEGMENTAL AREA}

\section{Connectivity}

Dopamine and particularly its projections to the ventral striatal complex are strongly implicated in the facilitation of approach behaviors and incentive learning (Horvitz, 2000; Wise, 2004; Fields et al, 2007; Ikemoto, 2007; Schultz, 2007; Redgrave et al, 2008). The above-cited reports indicate that activity of DA neurons is influenced by a host of novel stimuli that are initially unpaired with behavioral outcomes but are potentially salient by virtue of their high intensity and fast onset. DA neurons also respond to unexpected natural rewards and to conditioned cues that predict reward. DA release in forebrain regions may be involved 
in both the response to reward, and the facilitation of motivated actions that lead to reward in the future. Consequently, DA has a greater impact on instrumental behavior than on actual consumption (Wise, 2004). DA is particularly important for learning how certain behaviors lead to reward, and animals with DA depletion either cannot learn such associations or fail to maintain them (Wise and Rompre, 1989; Wise, 2004). The DA projection to the NAc also contributes to the rewards associated with drugs of abuse (Koob, 1992; Wise, 2004; Ikemoto, 2007), and plasticity in this system is strongly implicated in addictive disorders that involve compulsive drug-seeking (Wolf et al, 2004; Zweifel et al, 2008).

Neurons. Dopamine neurons make up about $60-65 \%$ of the cells in the VTA (Swanson, 1982; Nair-Roberts et al, 2008). They are highly heterogeneous and vary by location, morphological characteristics, forebrain targets, afferent influences, firing properties, and content of calciumbinding proteins, ion channels, autoreceptors, DA transporter, and other molecular features (Smith et al, 1996; Sesack and Carr, 2002; Björklund and Dunnett, 2007; Lammel et al, 2008; Margolis et al, 2008). Non-DA neurons in the ventral midbrain are primarily GABAergic and make up approximately $30-35 \%$ of the cells in the VTA (Swanson, 1982; Mugnaini and Oertel, 1985; Steffensen et al, 1998; Nair-Roberts et al, 2008). Although they are often referred to as interneurons, the predominant evidence indicates that these cells issue long-range projections that parallel those of DA neurons (Figure 1; Swanson, 1982; Van Bockstaele and Pickel, 1995; Steffensen et al, 1998; Carr and Sesack, 2000a). The functions of these GABA projections from the VTA have not yet been fully explored. Electrophysiological and anatomical evidence indicates that VTA GABA neurons also have local axon collaterals that innervate neighboring cells (Johnson and North, 1992; Nugent and Kauer, 2008; Omelchenko and Sesack, 2009).

Recently, a population of glutamate neurons also has been discovered in the VTA but not the SNc (Hur and Zaborszky, 2005; Kawano et al, 2006; Yamaguchi et al, 2007; Descarries et al, 2008). These appear to comprise approximately 2-3\% of VTA neurons (Nair-Roberts et al, 2008). The detailed connectivity of these cells will take time to decipher, given their low numbers and the fact that they can only be detected by in situ hybridization for VGlut2 mRNA, a selective marker of subcortical glutamate neurons (Herzog et al, 2001). Nevertheless, glutamatergic VTA cells have been shown to project at least to the PFC (Hur and Zaborszky, 2005) as well as locally (Dobi and Morales, 2007). A portion of VTA glutamate neurons also contains DA, and although some electrophysiological studies are interpreted as providing evidence of extensive colocalization of these transmitters (Chuhma et al, 2004; Lavin et al, 2005), this is not supported by anatomical studies. Rather, estimates regarding the degree of colocalization of DA and glutamate markers vary from as much as $20-50 \%$ in some VTA subdivisions (Kawano et al, 2006) to as little as $2 \%$ of all DA cells in the adult rat VTA (Yamaguchi et al, 2007).
The extent of colocalization also appears to be developmentally regulated (Descarries et al, 2008), being more extensive in perinatal animals and considerably diminished in adults. A clear delineation of the extent to which DA and glutamate are colocalized in the various projections of the VTA and the functional significance of such colocalization continue to be important topics for investigation.

Efferents. Dopamine and GABA cells in the ventral midbrain form a lateral to medial continuum and, in the rat at least, project in a roughly topographic manner to multiple forebrain regions with minimal branching but considerable overlap in the terminal fields (Fallon and Moore, 1978; Nauta et al, 1978; Beckstead et al, 1979; Swanson, 1982; Loughlin and Fallon, 1983; Deutch et al, 1988; Van Bockstaele and Pickel, 1995; Gaykema and Záborszky, 1996; Carr and Sesack, 2000a; Hasue and Shammah-Lagnado, 2002; Björklund and Dunnett, 2007; Del-Fava et al, 2007; Ikemoto, 2007; Lammel et al, 2008). There are also considerable interconnections between subdivisions of the nigra-VTA complex, which have recently been elegantly described by Shammah-Lagnado and co-workers (Ferreira et al, 2008); the majority of these intra-areal connections are likely to be non-dopaminergic (Dobi and Morales, 2007; Ferreira et al, 2008; Omelchenko and Sesack, 2009).

Cells in the SNc project primarily to the striatal complex, although the most extreme lateral portion of the SNc projects to the amygdala (Loughlin and Fallon, 1983). More medially positioned neurons at the border between the $\mathrm{SNc}$ and VTA project more ventrally within the basal ganglia (ie to the NAc), and cells in this region also project to the septum and other parts of the basal forebrain, olfactory tubercle, and amygdala (Swanson, 1982; Loughlin and Fallon, 1983; Gaykema and Záborszky, 1996; Hasue and Shammah-Lagnado, 2002; Björklund and Dunnett, 2007; Ikemoto, 2007; Lammel et al, 2008). Projections from the SNc and VTA also reach the pallidum and subthalamic nucleus (Klitenick et al, 1992; Gaykema and Záborszky, 1996; Hasue and Shammah-Lagnado, 2002; Björklund and Dunnett, 2007; Smith and Villalba, 2008). Within the VTA proper are DA and GABA neurons that project to the prefrontal, cingulated, and perirhinal cortices; some cortically projecting cells are also localized within the SNc (Carr and Sesack, 2000a; Björklund and Dunnett, 2007).

The medial most rostral linear VTA subdivision projects extensively to the olfactory tubercle, VP, preoptic and lateral hypothalamic areas, lateral habenular complex, mediodorsal thalamus, and supraoculomotor region; minor projections include the PFC, BLA, and dorsal raphe (Klitenick et al, 1992; Gaykema and Záborszky, 1996; DelFava et al, 2007). The majority of projections from the rostral linear nucleus appear to be non-dopaminergic (Swanson, 1982; Del-Fava et al, 2007). The caudomedial (ie caudolinear) and ventromedial VTA regions innervate the bed nucleus of the stria terminalis, the pallidum and basal forebrain, the central amygdaloid nucleus, and the 
BLA (Hasue and Shammah-Lagnado, 2002; Del-Fava et al, 2007).

In the primate, the relative segregation of cortically projecting neurons as arising from the VTA is not observed, and DA cells in the SNc have been shown to have cortical projections (Williams and Goldman-Rakic, 1998; Björklund and Dunnett, 2007). Moreover, the DA innervation to the cortex is more extensive in monkeys and humans, particular in primary motor areas (Lewis and Sesack, 1997). Regarding striatal pathways, a medial to lateral spiraling topography that also involves reciprocal feedback projections has been reported (see 'Efferents' in section Nucleus accumbens). Interestingly, as one shifts from medial to lateral cell groups in the rodent, the proportion of GABA neurons that project in parallel to the DA neurons declines, from as much as $60 \%$ in the mesoprefrontal projection to $15-35 \%$ in the mesoaccumbens projection and $5-15 \%$ in the nigrostriatal pathway (Swanson, 1982; Van Bockstaele and Pickel, 1995; Rodríguez and González-Hernández, 1999; Carr and Sesack, 2000a). Such contributions of GABA neurons to the ascending projections of the ventral midbrain have not been well studied in the monkey.

Recent tracing studies in the rat suggest that the projections of the VTA can be parceled in various ways depending on anatomical, physiological, and molecular features. An overall mediolateral topography in the efferent projections to the forebrain has long been recognized (Fallon and Moore, 1978; Beckstead et al, 1979). More recently, Ikemoto (2007) has put forward a model in which mesostriatal projections originating from the VTA consist of two major divisions: (1) a posterior division with projections to the medial, striatal portion of the olfactory tubercle and the medial NAc shell; and (2) a lateral VTA region projecting to the NAc core, lateral shell, and lateral olfactory tubercle. These observations can be interpreted within a broader literature detailing the stronger drug reward associations of the posteromedial $v s$ anterior VTA as well as the medial NAc shell and olfactory tubercle as compared to the other striatal regions (Ikemoto, 2007).

Historically, the ascending DA projections have also been divided into two portions along a dorsoventral dimension: (1) a dorsal tier of cells expressing low DA transporter and substantial calbindin projects to the cortex, ventral striatum (especially the NAc shell), limbic structures, and the striatal matrix; and (2) a ventral tier of neurons projects mainly to the striatal patch compartment and comprises neurons with higher DA transporter and lower calbindin levels (Gerfen, 1992; Haber et al, 1995; Björklund and Dunnett, 2007).

Finally, Lammel (Lammel et al, 2008) working in mouse brain has divided midbrain DA cells according to their forebrain targets and physiological characteristics, with (1) fast-spiking DA cells also expressing low ratios of mRNA for DA transporter $v s \mathrm{TH}$ and projecting to the PFC, NAc core, medial NAc shell, and BLA; and (2) slow-firing DA neurons projecting to the lateral NAc shell and dorsolateral striatum.
It will be important in future studies to determine exactly how each of these different population groupings contributes to the functions of the broader DA system.

Afferents: excitatory. The VTA receives input from widely distributed brain areas that have been described as forming a continuous band of afferent neurons not organized into discrete nuclei (Geisler and Zahm, 2005). This band stretches from the PFC to the medullary brainstem and follows the path of the medial forebrain bundle through the lateral hypothalamus. Cells in these areas have the morphological features and connectivity characteristic of the 'isodendritic core' originally attributed to the brainstem reticular formation (Ramón-Moliner and Nauta, 1966; Geisler and Zahm, 2005). Moreover, many of these structures provide only a modest input to the VTA, but they innervate other regions that are also afferent to the VTA. These observations imply that VTA neuronal activity is unlikely to be influenced by a discrete set of brain structures, and rather that DA neurons are regulated by an integrated network of inputs (Geisler and Zahm, 2005).

For years, the VTA was thought to have excitatory afferents from only a few sources. The bulk of the cortical mantle does not project to brainstem structures. Moreover, the hippocampus also has no direct projection to the brainstem, despite mediating an important physiological influence on VTA DA neurons (see 'Limbic modulation of VTA DA neuron activity' in section Ventral tegmental area). Hence, the only major cortical projection to the VTA originates from the PFC (Figure 1), including mainly the prelimbic and infralimbic cortices and less robustly the cingulate and orbital divisions (Beckstead, 1979; Phillipson, 1979a; Sesack et al, 1989; Sesack and Pickel, 1992b; Geisler and Zahm, 2005; Frankle et al, 2006; Geisler et al, 2007). The function of the PFC to VTA pathway in reward circuitry is unclear, although it appears to mediate an essential regulation of plasticity in DA neurons that can be altered by repeated exposure to drugs of abuse or stress (Wolf, 1998; Wolf et al, 2004).

Ultrastructural tract-tracing indicates that PFC axons synapse onto DA neurons that project back to the PFC, creating a circuit that allows the PFC to regulate the extent of its modulatory feedback by DA (Carr and Sesack, 2000b). Evidence has not been obtained for synapses from the prelimbic and infralimbic PFC onto mesoaccumbens DA neurons (Carr and Sesack, 2000b), although these cells might receive cortical input from structures outside the medial regions that were examined by tract-tracing (Geisler et al, 2007; Omelchenko and Sesack, 2007). GABA VTA neurons are also innervated by PFC synapses, and these appear to project mainly to the NAc as opposed to the PFC (Carr and Sesack, 2000b). Other populations of VTA DA or GABA cells defined by target projection have not yet been examined with regard to PFC synaptic input.

The PPTg and laterodorsal tegmentum (LDT) also provide an important input to the SNc and VTA (Figure 1; Lavoie and Parent, 1994; Oakman et al, 1995; Charara et al, 1996; Mena-Segovia et al, 2008). Within the ventral 
midbrain, the VTA is innervated by the LDT and caudal PPTg, whereas the SNc is innervated primarily by the rostral PPTg (Mena-Segovia et al, 2008). The SNr receives only minimal input. Synapses from the PPTg/LDT contact both DA and non-DA GABAergic neurons within the VTA of both rat and monkey (Charara et al, 1996; Omelchenko and Sesack, 2005). Ultrastructural evidence suggests that these projections originate from cholinergic, glutamatergic, and GABAergic neurons (Charara et al, 1996; Garzón et al, 1999; Omelchenko and Sesack, 2005, 2006). The use of tracttracing in combination with immunocytochemistry reveals that probable glutamatergic and cholinergic LDT neurons synapse onto DA cells that project to the NAc (Omelchenko and Sesack, 2005, 2006). These findings are consistent with neurochemical observations that blockade of cholinergic and glutamatergic receptors in the VTA alters the ability of $\mathrm{PPTg} / \mathrm{LDT}$ stimulation to evoke DA release in the NAc (Blaha et al, 1996; Forster and Blaha, 2000).

The results of anatomical studies are also consistent with electrophysiological evidence that the PPTg-LDT complex excites DA cells and promotes burst firing (Futami et al, 1995; Lokwan et al, 1999; Floresco et al, 2003; Lodge and Grace, 2006b) (see 'Limbic modulation of VTA DA neuron activity' in section Ventral tegmental area). The fact that inhibitory responses are less often recorded, even though GABA cells make up $30-40 \%$ of PPTg/LDT neurons (Wang and Morales, 2009), may relate to observations that inhibitory-type synapses from this region tend to innervate VTA GABA neurons more often than DA cells (Omelchenko and Sesack, 2005). Such a disinhibitory organization might be expected to facilitate the recruitment of burst firing in DA neurons.

Recently, the seminal work of Geisler et al (2007) using retrograde tract-tracing in combination with in situ hybridization for VGlut subtypes has revealed multiple sources of glutamate afferents to the VTA, many of which had not been previously appreciated. Afferents expressing VGlut1 derive primarily from the medial and lateral PFC, including the prelimbic, infralimbic, dorsal peduncular, cingulate, and orbital cortices. VGlut2-containing afferents derive from multiple subcortical sites, including in relative order of predominance: the lateral hypothalamus, lateral preoptic area, periaqueductal gray, medial hypothalamus, VP, mesopontine reticular formation, lateral habenula, $\mathrm{PPTg} / \mathrm{LDT}$, and other regions (Figure 1). The presumed monosynaptic excitatory glutamate influence of the bed nucleus of the stria terminalis (Georges and Aston-Jones, 2002) has only scant confirmation by anatomical analysis (Geisler et al, 2007). Afferents to the VTA expressing VGlut3, a marker that has not yet been proven to correlate with glutamate transmission, arise primarily from raphe nuclei (Geisler et al, 2007). The revelation of so many new sources of glutamate input to the VTA has important implications for understanding how information related to reward behavior reaches this brain region. Nevertheless it will take time to delineate the functional role that each of these new projections mediates.
The findings of Geisler et al are consistent with ultrastructural data indicating that the dominant sources of glutamate afferents to the VTA are VGlut2 containing and therefore from non-cortical structures (Omelchenko and Sesack, 2007). Axons containing VGlut2 synapse extensively onto mesoaccumbens DA neurons, suggesting that many different brain regions contribute to the activation of one of the main pathways implicated in control of motivated behaviors. Mesoprefrontal DA cells also receive VGlut2 afferents, but a significant portion of their synapses is from VGlut1-containing axons, consistent with their more selective innervation from the PFC (Carr and Sesack, 2000b).

Some excitatory influences of the VTA are driven by peptides as opposed to classical neurotransmitters. For example, orexin afferents from the hypothalamus (Fadel et al, 2002) mediate an importance influence on reward behaviors (Harris et al, 2005) and synaptic plasticity (Borgland et al, 2006) presumably by excitatory actions on DA cells (Korotkova et al, 2003). The anatomical substrates for this influence are not yet clear, given that few orexin axons actually synapse within the VTA, and only half of these contact DA cells (Balcita-Pedicino and Sesack, 2007). Neurotensin- and corticotropin-releasing factors from multiple sources also mediate important excitatory influences on VTA DA cells (Geisler and Zahm, 2006; Reynolds et al, 2006; Rodaros et al, 2007; Tagliaferro and Morales, 2008; Wanat et al, 2008).

Afferents: inhibitory/modulatory. A complete list of sources of inhibitory GABA signals to the VTA has not yet been delineated in the same thorough manner as glutamate inputs. Nevertheless, a major inhibitory feedback from the basal ganglia is well known and likely to constitute the bulk of the inhibitory synapses in the VTA (Geisler and Zahm, 2005) as in the SNc (Somogyi et al, 1981; Smith and Bolam, 1990). These projections arise from the NAc shell and VP (Zahm and Heimer, 1990; Heimer et al, 1991; Zahm et al, 1996; Usuda et al, 1998). Additional inhibitory afferents to the VTA are likely to arise from the lateral hypothalamus and other hypothalamic regions, diagonal band, bed nucleus, lateral septum, periaqueductal gray, PPTg/LDT, parabrachial, and raphe nuclei (Geisler and Zahm, 2005). Many of these projections also contain neuroactive peptides and mediate complex actions on midbrain neurons (Sesack and Pickel, 1992a; Pickel et al, 1993; Dallvechia-Adams et al, 2002; Ford et al, 2006). A substantial projection exists from the central nucleus of the amygdala to the lateral SNc (ie reciprocal to the source of DA input to the amygdala) (Gonzales and Chesselet, 1990; Zahm, 2006), but only occasional fibers from this or any other amygdala division reach the medial SNc or VTA in the rat (Zahm et al, 2001; Geisler and Zahm, 2005; Zahm, 2006). In the primate, one study reported a robust projection from the central amygdaloid nucleus to the VTA (Fudge and Haber, 2000), although another paper described this connection as modest (Price and Amaral, 1981). These findings might represent an interesting and important species difference; nevertheless a substantial 
projection from the central amygdala to the VTA remains to be confirmed (for important technical considerations see Zahm, 2006).

In addition to the well-known afferents listed above, a new major ascending source of inhibition to the SNc and VTA has only recently been discovered and named. The mesopontine rostromedial tegmental nucleus (RMTg) lies just caudal to the VTA, dorsomedial to the medial lemniscus, dorsolateral to the interpeduncular nucleus, and lateral to the median raphe (Jhou et al, 2009b; Kaufling et al, 2009). It receives afferents from many forebrain and brainstem structures (Jhou et al, 2009b), consists primarily of GABA cells (Perrotti et al, 2005; Olson and Nestler, 2007; Kaufling et al, 2009), and has extensive projections to the entire SNc-VTA complex (Figure 1; Colussi-Mas et al, 2007; Ferreira et al, 2008; Geisler et al, 2008; Jhou et al, 2009b). It is therefore in a critical position to inhibit DA cell firing in response to aversive stimuli (Grace and Bunney, 1979; Ungless et al, 2004; Jhou et al, 2009a) or when expected rewards are not delivered (Schultz, 1998b). The latter influence is likely to arise first in the lateral habenula, which is activated by the absence of reward (Matsumoto and Hikosaka, 2007), has projections to the VTA and RMTg (Herkenham and Nauta, 1979; Araki et al, 1988; Bell et al, 2007; Jhou et al, 2009b; Kaufling et al, 2009), and mediates a nearly ubiquitous inhibitory influence on DA cell activity (Ji and Shepard, 2007; Matsumoto and Hikosaka, 2007; Hikosaka et al, 2008). Cells in the RMTg are activated by stress and by psychostimulant exposure (Perrotti et al, 2005; Colussi-Mas et al, 2007; Jhou and Gallagher, 2007; Geisler et al, 2008; Jhou et al, 2009a,b; Kaufling et al, 2009), indicating that the RMTg may be a critical structure regulating the responses of $\mathrm{DA}$ cells to natural and drug rewards as well as their converse events.

In addition to the various extrinsic sources of inhibition, VTA DA neurons also receive inhibitory synapses from neighboring GABA cells (Figure 1). Such inputs have been reported in light microscopic and physiology studies (Grace and Bunney, 1979; Phillipson, 1979b; Grace and Onn, 1989; Johnson and North, 1992; Nugent and Kauer, 2008) but only recently confirmed by ultrastructural analysis (Omelchenko and Sesack, 2009). The local collaterals of GABA neurons also synapse onto GABA cells (Omelchenko and Sesack, 2009), creating the potential circuitry for disinhibitory actions on DA neurons (Celada et al, 1999; Fields et al, 2007).

The VTA also receives afferents from other brainstem monoamine groups that produce variable actions on target neurons depending on receptor type. Serotonin neurons in the dorsal raphe nucleus synapse onto DA cells (Hervé et al, 1987; Van Bockstaele et al, 1994) and mediate primarily inhibition (Gervais and Rouillard, 2000), although excitatory actions are also reported (Pessia et al, 1994). The ventral midbrain also receives inputs from the LC and other medullary norepinephrine cell groups (Liprando et al, 2004; Geisler and Zahm, 2005; Mejías-Aponte et al, 2009). Either excitatory or inhibitory actions of norepinephrine are produced on DA cells, mediated by $\alpha-1$ and $\alpha-2$ receptors, respectively, as well as more complex indirect actions (Grenhoff et al, 1995; Arencibia-Albite et al, 2007; Guiard et al, 2008). These inputs provide a pathway for visceral and homeostatic information to reach DA and non-DA cells in the VTA.

In summary, the VTA receives a rich assortment of influences from multiple ascending and descending and even intrinsic sources. The functional significance of each afferent in relation to reward has yet to be determined. For example, it is not known how the sensory information regarding receipt of an unpredicted reward reaches DA neurons. It is also unclear by what route visual and auditory information influence DA cell firing when these serve as conditioning cues that predict reward. Certainly VTA DA cells fire in response to visual cues in a manner that correlates with activity in neurons of the superior colliculus (Coizet et al, 2003; Dommett et al, 2005). However, the projection from the superior colliculus to the VTA is considerably weaker than its input to the $\mathrm{SNc}$, and it is also not entirely glutamatergic (Comoli et al, 2003; Geisler and Zahm, 2005; Geisler et al, 2007). This raises the possibility that there are alternative pathways for sensory information to reach the VTA that remain to be elucidated.

\section{Regulation of VTA Activity and its Role in Reward}

Limbic modulation of VTA DA neuron activity. Dopamine neurons are known to exhibit different states of activity that depend on their intrinsic properties and afferent drive. The baseline activity of DA neurons is driven by a pacemaker conductance that brings the neuronal membrane potential from a very hyperpolarized state to its relatively depolarized spike threshold (Grace and Bunney, 1983, 1984b; Grace and Onn, 1989). This pacemaker conductance is responsible for the baseline activity of the neurons, which is then modulated up or down from this state. Although this pacemaker conductance causes the DA neurons to fire in a highly regular pacemaker pattern in vitro (Grace and Onn, 1989), this pattern is replaced by an irregular pattern when it is distorted by the constant bombardment of GABA IPSPs (Grace and Bunney, 1985). However, studies have shown that not all of the DA neurons in the SNc/VTA are firing spontaneously. Thus, evidence shows that a majority of DA neurons in anesthetized (Bunney and Grace, 1978; Grace and Bunney, 1984b) or awake (Freeman et al, 1985) animals are in a hyperpolarized, non-firing state. This is apparently because of a powerful inhibitory input arising from the VP. The VP, in turn, is under the inhibitory control of the NAc. The proportion of DA neurons firing spontaneously, which is termed the 'population activity', depends primarily on the vSub inputs to the NAc; thus, the vSub will drive NAc inhibition of the VP, and thereby disinhibit DA neurons (Floresco et al, 2001, 2003). The role of the vSub in controlling the number of DA neurons firing spontaneously is consistent with its overall function in context-dependent processing, in that the state of activation of DA neurons can potently modulate the attentional state of the organism. 
In addition to being modulated between a silent, nonfiring state, and a condition of irregular activity, DA neurons can also exhibit burst firing. Burst firing is induced in DA neurons whenever behaving animals encounter a behaviorally salient stimulus such as one predicting reward (Schultz, 1998a). Burst firing is dependent on a glutamatergic drive of DA neurons acting on NMDA receptors (Grace and Bunney, 1984a; Chergui et al, 1993). The most potent driver of mesolimbic DA neuron burst firing appears to derive from glutamatergic afferents arising from the PPTg (Floresco and Grace, 2003; Lodge and Grace, 2006a). Moreover, the LDT provides a permissive gate over the ability of the PPTg to induce burst firing (Lodge and Grace, 2006b). Thus, the PPTg/LDT drives the behaviorally salient burst discharge of DA neurons. However, in order for this NMDA-mediated burst firing to take place, the DA neuron must be in a spontaneously firing condition (Floresco et al, 2003). The spontaneous firing state is dependent on input from the vSub-NAc-VP-VTA pathway (Figure 3). Thus, only neurons placed in a spontaneously firing state by the vSub system can respond to the PPTg with a burst of spikes. In this situation, the PPTg provides the behaviorally salient 'signal,' whereas the vSub provides the amplification factor, or 'gain,' of this signal (Lodge and Grace, 2006a; Figure 3).

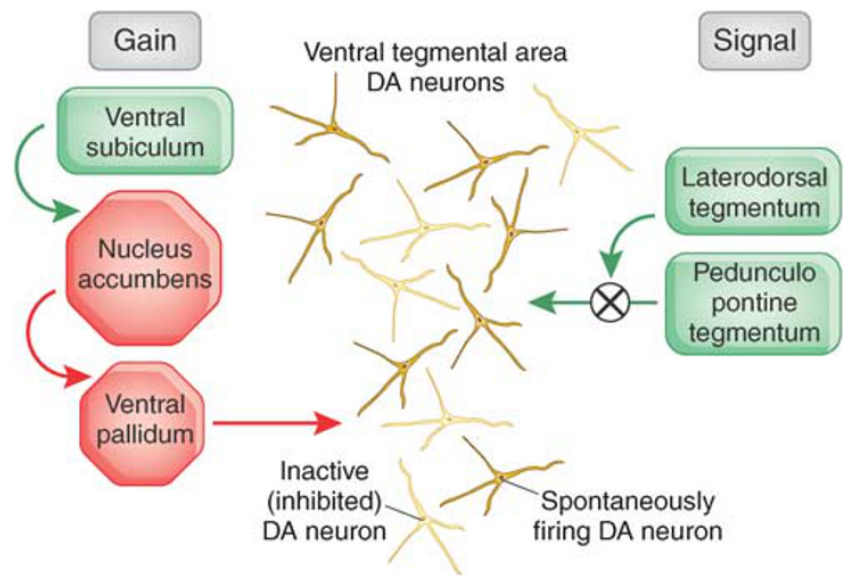

Figure 3. DA neurons in the VTA can exist in several activity states. In the basal, unstimulated state, DA neurons fire spontaneously at a slow, irregular rate. The VP provides a potent GABAergic input to DA neurons, causing a proportion of them to be tonically inhibited and non-firing. The VP in turn is controlled by afferents from the vSub and the NAc. When the vSub is activated, it provides a glutamatergic drive to the NAc, which in turn inhibits the VP and releases DA neurons from inhibition, allowing them to fire spontaneously. In contrast, the PPTg provides a potent direct glutamatergic input to DA neurons; when the PPTg is activated, it causes DA neurons to fire in bursts, which is believed to be the behaviorally salient pattern signaling a rewarding event. The impact of the PPTg, however, is gated by the LDT; only when the LDT is active can the PPTg initiate burst firing. In order for a DA neuron to burst fire, it must first be firing spontaneously. Given that the vSub controls the proportion of DA neurons firing spontaneously, it also sets the number of DA neurons that can be made to burst fire by the PPTg. As such, the PPTg drives the behaviorally salient burst firing, whereas the vSub provides the 'gain' or amplification of the signal. The greater the vSubdriven gain, the larger the DA response produced by a stimulus that activates the PPTg.
The higher the activity of the vSub, the larger the number of DA neurons that can be driven into a burst firing mode.

This organization would therefore permit the vSub to control the amplitude of the phasic burst firing response of the DA neurons. This is consistent with the role of the vSub in regulating context-dependent responses (Jarrard, 1995; Maren, 1999; Sharp, 1999; Fanselow, 2000). In conditions in which expectation would powerfully affect the magnitude of response to a stimulus, the vSub would be critical in controlling the amplitude of the DA neuron activation. Thus, if one were in a condition in which stimuli would have a high reward value (eg a casino), the ringing of a bell would be much more highly reinforcing than in other contexts (eg a church). Thus, the vSub provides a contextdependent modulation of the amplitude of the DA response to stimuli (Grace et al, 2007).

Alteration of DA neuron signaling. The state of the DA system can powerfully influence the response to stimuli occurring naturally and also pharmacologically. For example, the population activity of the DA neurons will affect the manner in which the DA system responds to drugs such as amphetamine. In cases in which the DA neuron population activity is high, there is an increase in the locomotor response to amphetamine injection; this can be reversed by inactivation of the vSub (Lodge and Grace, 2008). This is particularly true for manipulations in which the behavioral response has a contextual component. Thus, with repeated amphetamine administration, a behavioral sensitization to subsequent doses of amphetamine is produced, in which the same dose of drug will produce an exaggerated response when the animal is withdrawn from a repeated amphetamine treatment regimen (Segal and Mandell, 1974; Post and Rose, 1976). Moreover, the amplitude of the response is greatest if the test dose of amphetamine is given in the same environmental context as the original treatment (Vezina et al, 1989; Badiani et al, 2000; Crombag et al, 2000). During withdrawal from amphetamine sensitization, the increased behavioral response occurs in parallel with an increase in vSub firing and in the population activity of DA neurons (Lodge and Grace, 2008). Moreover, both the behavioral sensitization and the DA neuron population activity can be restored to baseline by inactivation of the vSub. A unique type of LTP due to AMPA receptor alteration (Bellone and Luscher, 2006) in VTA DA neurons following single or multiple doses of stimulants (Vezina and Queen, 2000; Ungless et al, 2001; Faleiro et al, 2003; Borgland et al, 2004; Faleiro et al, 2004; Schilstrom et al, 2006) may also have a function in the establishment of sensitization, particularly as this may potentiate the phasic DA responsiveness of the system. However, the induction with single drug doses and the short-lived (ie $<10$ days) nature of the response makes it insufficient in itself to account for the long-term sensitization process. Nonetheless, the necessary yet transient (Zhang et al, 1997) NMDA stimulation-dependent LTP (Kalivas, 1995; Vezina and Queen, 2000; Suto et al, 2003; Borgland et al, 2004) in the VTA that is required for sensitization may be necessary to supply NAc DA that will potentiate vSub-NAc inputs (Goto and Grace, 2005b). This in turn will allow the D1-dependent LTP that occurs in the 
vSub-NAC pathway in response to cocaine sensitization (Goto and Grace, 2005a). These data are also consistent with findings that, whereas glutamatergic mechanisms in the VTA are required for the induction of sensitization, the expression of sensitization is mediated by processes within the VTA (Kalivas and Stewart, 1991).

In contrast to sensitization, drug-seeking behavior such as that induced by drug self-administration appears to be dependent on a different process that reflects drugbehavior associations (Everitt and Robbins, 2005; Hyman et al, 2006). Interestingly, the induction of LTP in VTA DA neurons that is driven by cocaine self-administration appears to be uniquely persistent, lasting up to 3 months and persisting even after behavioral extinction of drugseeking behavior has taken place (Chen et al, 2008). Thus, these longer-term changes appear to contribute to modifications that are better associated with drug-seeking behavior than with drug sensitization. In the case of drug sensitization, both experimenter injection-induced and self-administration-induced sensitization appear to exhibit similar actions with respect to the behavioral profile.

Amphetamine sensitization also is present with other types of context-dependent responses such as stress. Stress is known to be a context-dependent phenomenon, in that animals exhibit heightened responses to stressors when tested in an environment in which they had been previously exposed to stressors (Bouton and Bolles, 1979; Bouton and King, 1983). Moreover, stressors such as restraint are known to also increase the behavioral response to amphetamine (Pacchioni et al, 2002). In concert with this observation, a similar $2 \mathrm{~h}$ restraint stress will also increase the population activity of DA neurons (Valenti and Grace, 2008), and both the augmented behavioral response and the stress-induced increase in DA neuron population activity can be reversed by vSub inactivation.

\section{CLINICAL IMPLICATIONS}

The reward circuits that drive motivated behaviors are implicated in a broad array of disease states. Deficits in reward-related activity are central to the anhedonia of depression (Hyman et al, 2006), and altered stimulus valuation is also a known component of attention-deficit hyperactivity disorder and obsessive-compulsive disorder (Cardinal et al, 2004; Everitt et al, 2008; Huey et al, 2008). The integration of affective and cognitive processes that support optimal goal-directed behavior is critically regulated by the frontal cortex, and inadequate output from this region contributes to mental disorders ranging from schizophrenia to depression to drug abuse. Such a commonality of pathology may have its expression in the increasing convergence of treatment strategies, such as second-generation antipsychotic drugs now being used to treat depression and bipolar disorder (Ketter, 2008; Mathew, 2008). A greater understanding of systems integration on a basic neuroscience level may provide a neurobiological basis for interpreting novel findings from human imaging studies and a focus on disease endophenotypes that leads to a more individualized approach to the treatment of psychiatric disorders.

\section{FUTURE RESEARCH DIRECTIONS}

Limbic circuitry and its interactions with DA neurons provide the means for altering reward-related responding based on experience. The responsivity of the DA system is potently regulated by context and behaviorally salient stimuli. In turn, the output of DA neurons provides a critical modulation of the systems that regulate goaldirected behaviors, in particular the NAc. Such interconnected loops not only regulate behavioral responses but also select which salient stimuli are established into memory (Lisman and Grace, 2005). It is through such malleable, experience-dependent plasticity, subject to multiple nodes of influence that an organism can most successfully adapt to its environment. Conversely, disruption of these systems through developmental dysregulation, pharmacological intervention, or pathological stressors can lead to severely maladaptive responses in the form of mental and addictive disorders. Such concepts are most effectively derived from an integration of systems neuroscience with cellular and molecular analyses in normal and diseased states. By understanding the dynamics of these systems, the ability to treat or even prevent these conditions may be realized.

\section{ACKNOWLEDGEMENTS}

This work was funded by NIH.

\section{DISCLOSURE}

SRS has received compensation for professional services from National Institutes of Drug Abuse; AAG has received compensation for professional services from Abbott, Boehringer Ingelheim, Galaxo SmithKlein, Johnson \& Johnson, Lilly, Lundbeck AstraZeneca, Novartis, Phillips/ Lyttel representing Galaxo Smith Klein, Roche, SchiffHarden representing Sandoz Pharmaceutical, and Taisho over the past 3 years.

\section{REFERENCES}

The highlighted references refer to significant original research papers that are recommended for the readership. This chapter contains many references to noteworthy publications from the dorsal striatum, PFC, amygdala, basal forebrain, and other regions. However, here we have chosen to highlight papers from the NAc and VTA systems that are the major subjects of this review.

\footnotetext{
Alcantara AA, Chen V, Herring BE, Mendenhall JM, Berlanga ML (2003). Localization of dopamine D2 receptors on cholinergic interneurons of the dorsal striatum and nucleus accumbens of the rat. Brain Res 986: 22-29.
} 
Alexander GE, Crutcher MD, DeLong MR (1990). Basal ganglia-thalamocortical circuits: parallel substrates for motor, oculomotor, 'prefrontal' and 'limbic' functions. Prog Brain Res 85: 119-146.

Alheid GF, Heimer L (1988). New perspectives in basal forebrain organization of special relevance for neuropsychiatric disorders: the striatopallidal, amygdaloid, and corticopetal components of substantia innominata. Neuroscience 27: 1-39.

Amaral DG, Dolorfo C, Alvarez-Royo P (1991). Organization of CA1 projections to the subiculum: a PHA-L analysis in the rat. Hippocampus 1: 415-435.

Ambroggi F, Ishikawa A, Fields HL, Nicola SM (2008). Basolateral amygdala neurons facilitate reward-seeking behavior by exciting nucleus accumbens neurons. Neuron 59: 648-661.

Araki M, McGeer PL, Kimura H (1988). The efferent projections of the rat lateral habenular nucleus revealed by the PHA-L anterograde tracing method. Brain Res 441: 319-330

Arencibia-Albite F, Paladini C, Williams JT, Jiménez-Rivera CA (2007). Noradrenergic modulation of the hyperpolarization-activated cation current (Ih) in dopamine neurons of the ventral tegmental area. Neuroscience 149: 303-314.

Bacon SJ, Headlam AJN, Gabbott PLA, Smith AD (1996). Amygdala input to media prefrontal cortex (mPFC) in the rat: a light and electron microscopic study. Brain Res 720: 211-219.

Badiani A, Oates MM, Fraioli S, Browman KE, Ostrander MM, Xue CJ et al (2000). Environmental modulation of the response to amphetamine: dissociation between changes in behavior and changes in dopamine and glutamate overflow in the rat striatal complex. Psychopharmacology 151: 166-174.

Balcita-Pedicino JJ, Sesack SR (2007). Orexin axons in the rat ventral tegmenta area synapse infrequently onto dopamine and gamma-aminobutyric acid neurons. J Comp Neurol 503: 668-684.

Beckstead RM (1979). An autoradiographic examination of corticocortical and subcortical projections of the mediodorsal-projection (prefrontal) cortex in the rat. J Comp Neurol 184: 43-62.

Beckstead RM, Domesick VB, Nauta WJH (1979). Efferent connections of the substantia nigra and ventral tegmental area in the rat. Brain Res 175: 191-217.

Bell RL, Omelchenko N, Sesack SR (2007). Lateral habenula projections to the ventral tegmental area in the rat synapse onto dopamine and GABA neurons. Soc Neurosc Abstr 33: 780.9.

Bellone C, Luscher C (2006). Cocaine triggered AMPA receptor redistribution is reversed in vivo by mGluR-dependent long-term depression. Nat Neurosci $\mathbf{9}$ 636-641.

Belujon P, Grace AA (2008). Critical role of the prefrontal cortex in the regulation of hippocampus-accumbens information flow. J Neurosci 28: 9797-9805. This paper demonstrated that the PFC is required to facilitate ventral hippocampal excitation of the NAc, which has relevance to both models of plasticity and cortical modulation of subcortical circuits.

Bennett BD, Bolam JP (1994). Synaptic input and output of parvalbumin-immunoreactive neurons in the neostriatum of the rat. Neuroscience 62: 707-719.

Berendse HW, Galis-de Graaf Y, Groenewegen HJ (1992). Topographical organization and relationship with ventral striatal compartments of prefrontal corticostriatal projections in the rat. J Comp Neurol 316: 314-347.

Berendse HW, Groenewegen HJ (1990). Organization of the thalamostriatal projections in the rat, with special emphasis on the ventral striatum. J Comp Neurol 299: 187-228.

Berke JD (2003). Learning and memory mechanisms involved in compulsive drug use and relapse. Methods $\mathrm{Mol}$ Med 79: 75-101. This paper provided important new insights into habit formation, and the transition from rewards to habits during drug-reinforced behavior.

Berke JD (2008). Uncoordinated firing rate changes of striatal fast-spiking interneurons during behavioral task performance. J Neurosci 28: 10075-10080.

Bittencourt JC, Presse F, Arias C, Peto C, Vaughan J, Nahon JL et al (1992). The melanin-concentrating hormone system of the rat brain: an immuno- and hybridization histochemical characterization. J Comp Neurol 319: 218-245.

Björklund A, Dunnett SB (2007). Dopamine neuron systems in the brain: an update. Trends Neurosci 30: 194-202.

Blaha CD, Allen LF, Das S, Inglis WL, Latimer MP, Vincent SR et al (1996). Modulation of dopamine efflux in the nucleus accumbens after cholinergic stimulation of the ventral tegmental area in intact, pedunculopontine tegmental nucleus-lesioned, and laterodorsal tegmental nucleus-lesioned rats. J Neurosci 16: 714-722.

Blomeley CP, Kehoe LA, Bracci E (2009). Substance P mediates excitatory interactions between striatal projection neurons. J Neurosci 29: 4953-4963.

Bonson KR, Grant SJ, Contoreggi CS, Links JM, Metcalfe J, Weyl HL et al (2002). Neural systems and cue-induced cocaine craving. Neuropsychopharmacology 26: 376-386.

Borgland SL, Malenka RC, Bonci A (2004). Acute and chronic cocaine-induced potentiation of synaptic strength in the ventral tegmental area: electrophysiological and behavioral correlates in individual rats. J Neurosci 24: 7482-7490.
Borgland SL, Taha SA, Sarti F, Fields HL, Bonci A (2006). Orexin A in the VTA is critical for the induction of synaptic plasticity and behavioral sensitization to cocaine. Neuron 49: 589-601. Orexin is gaining increasing recognition as a modulator of attentional and reward states, and this paper detailed how this peptide can affect DA systems.

Bouton ME, Bolles RC (1979). Role of conditioned contextual stimuli in reinstatement of extinguished fear. J Exp Psychol Anim Behav Process 5: 368-378.

Bouton ME, King DA (1983). Contextual control of the extinction of conditioned fear: tests for the associative value of the context. J Exp Psychol Anim Behav Process 9: 248-265.

Bouyer JJ, Park DH, Joh TH, Pickel VM (1984). Chemical and structural analysis of the relation between cortical inputs and tyrosine hydroxylase-containing terminals in rat neostriatum. Brain Res 302: 267-275.

Brady AM, O'Donnell P (2004). Dopaminergic modulation of prefrontal cortical input to nucleus accumbens neurons in vivo. J Neurosci 24: 1040-1049.

Brinley-Reed M, Mascagni F, McDonald AJ (1995). Synaptology of prefrontal cortical projections to the basolateral amygdala: an electron microscopic study in the rat. Neurosci Lett 202: 45-48.

Brog JS, Salyapongse A, Deutch AY, Zahm DS (1993). The patterns of afferent innervation of the core and shell in the 'accumbens' part of the rat ventral striatum: immunohistochemical detection of retrogradely transported fluoro-gold. J Comp Neurol 338: 255-278. This paper detailed the major cortical and subcortical inputs to the core and shell subterritories of the NAc.

Brown P, Molliver ME (2000). Dual serotonin (5-HT) projections to the nucleus accumbens core and shell: relation of the 5-HT transporter to amphetamineinduced neurotoxicity. J Neurosci 20: 1952-1963.

Bunney BS, Grace AA (1978). Acute and chronic haloperidol treatment: comparison of effects on nigral dopaminergic cell activity. Life Sci 23: 1715-1727.

Cardinal RN, Winstanley CA, Robbins TW, Everitt BJ (2004). Limbic corticostriatal systems and delayed reinforcement. Ann NY Acad Sci 1021: 33-50.

Carlezon Jr WA, Devine DP, Wise RA (1995). Habit-forming actions of nomifensine in nucleus accumbens. Psychopharmacology 122: 194-197.

Carlezon Jr WA, Thomas MJ (2009). Biological substrates of reward and aversion: a nucleus accumbens activity hypothesis. Neuropharmacology 56(Suppl 1): 122-132.

Carr DB, Sesack SR (2000a). GABA-containing neurons in the rat ventral tegmental area project to the prefrontal cortex. Synapse 38: 114-123. This paper established that most of the VTA projection to the PFC derives from GABA as opposed to DA cells.

Carr DB, Sesack SR (2000b). Projections from the rat prefrontal cortex to the ventra tegmental area: target specificity in the synaptic associations with mesoaccumbens and mesocortical neurons. J Neurosci 20: 3864-3873. This publication was the first to provide evidence consistent with different populations of VTA DA neurons having distinct sources of afferent drive.

Celada P, Paladini CA, Tepper JM (1999). GABAergic control of rat substantia nigra dopaminergic neurons: role of globus pallidus and substantia nigra pars reticulata. Neuroscience 89: 813-825.

Cepeda C, Buchwald NA, Levine MS (1993). Neuromodulatory actions of dopamine in the neostriatum are dependent on the excitatory amino acid receptor subtypes activated. Proc Natl Acad Sci 90: 9576-9580.

Cepeda C, Colwell CS, Itri JN, Chandler SH, Levine MS (1998). Dopaminergic modulation of NMDA-induced whole cell currents in neostriatal neurons in slices: contribution of calcium conductances. J Neurophysiol 79: 82-94.

Charara A, Grace AA (2003). Dopamine receptor subtypes selectively modulate excitatory afferents from the hippocampus and amygdala to rat nucleus accumbens neurons. Neuropsychopharmacology 28: 1412-1421.

Charara A, Smith Y, Parent A (1996). Glutamatergic inputs from the pedunculopontine nucleus to midbrain dopaminergic neurons in primates: Phaseolus vulgaris-leucoagglutinin anterograde labeling combined with postembedding glutamate and GABA immunohistochemistry. J Comp Neurol 364: 254-266. This paper provided the first anatomical evidence for an ascending subcortical excitatory projection that synapses onto VTA DA neurons.

Chen BT, Bowers MS, Martin M, Hopf FW, Guillory AM, Carelli RM et al (2008). Cocaine but not natural reward self-administration nor passive cocaine infusion produces persistent LTP in the VTA. Neuron 59: 288-297.

Chergui K, Charlety PJ, Akaoka H, Saunier CF, Brunet J-L, Svensson TH et al (1993). Tonic activation of NMDA receptors causes spontaneous burst discharge of rat midbrain dopamine neurons in vivo. Eur J Neurosci 5: 137-144.

Chergui K, Lacey MG (1999). Modulation by dopamine D1-like receptors of synaptic transmission and NMDA receptors in rat nucleus accumbens is attenuated by the protein kinase $\mathrm{C}$ inhibitor Ro 32-0432. Neuropharmacology 38: 223-231.

Chuhma N, Zhang H, Masson J, Zhuang X, Sulzer D, Hen R et al (2004). Dopamine neurons mediate a fast excitatory signal via their glutamatergic synapses. J Neurosci 24: 972-981. 
Churchill L, Kalivas PW (1994). A topographically organized gamma-aminobutyric acid projection from the ventral pallidum to the nucleus accumbens in the rat. J Comp Neurol 345: 579-595.

Coizet V, Comoli E, Westby GW, Redgrave P (2003). Phasic activation of substantia nigra and the ventral tegmental area by chemical stimulation of the superior colliculus: an electrophysiological investigation in the rat. Eur J Neurosci 17: 28-40.

Colussi-Mas J, Geisler S, Zimmer L, Zahm DS, Berod A (2007). Activation of afferents to the ventral tegmental area in response to acute amphetamine: a double-labelling study. Eur J Neurosci 26: 1011-1025.

Comoli E, Coizet V, Boyes J, Bolam JP, Canteras NS, Quirk RH et al (2003). A direct projection from superior colliculus to substantia nigra for detecting salient visual events. Nat Neurosci 6: 974-980.

Crombag HS, Badiani A, Maren S, Robinson TE (2000). The role of contextual vs discrete drug-associated cues in promoting the induction of psychomotor sensitization to intravenous amphetamine. Behav Brain Res 116: 1-22. This paper provided an important link between environment and behavioral sensitization by demonstrating how context can modify behavioral expression.

Dallvechia-Adams S, Kuhar MJ, Smith Y (2002). Cocaine- and amphetamineregulated transcript peptide projections in the ventral midbrain: colocalization with g-aminobutyric acid, melanin-concentrating hormone, dynorphin, and synaptic interactions with dopamine neurons. J Comp Neurol 448: 360-372.

Dallvechia-Adams S, Smith Y, Kuhar MJ (2001). CART peptide-immunoreactive projection from the nucleus accumbens targets substantia nigra pars reticulata neurons in the rat. J Comp Neurol 434: 29-39.

Day M, Wang Z, Ding J, An X, Ingham CA, Shering AF et al (2006). Selective elimination of glutamatergic synapses on striatopallidal neurons in Parkinson disease models. Nat Neurosci 9: 251-259.

Del-Fava F, Hasue RH, Ferreira JG, Shammah-Lagnado SJ (2007). Efferent connections of the rostral linear nucleus of the ventral tegmental area in the rat. Neuroscience 145: 1059-1076.

Delfs JM, Zhu Y, Druhan JP, Aston-Jones GS (1998). Origin of noradrenergic afferents to the shell subregion of the nucleus accumbens: anterograde and retrograde tract-tracing studies in the rat. Brain Res 806: 127-140.

Deng YP, Lei WL, Reiner A (2006). Differential perikaryal localization in rats of D1 and D2 dopamine receptors on striatal projection neuron types identified by retrograde labeling. J Chem Neuroanat 32: 101-116.

Descarries L, Berube-Carriere N, Riad M, Bo GD, Mendez JA, Trudeau LE (2008). Glutamate in dopamine neurons: synaptic vs diffuse transmission. Brain Res Rev 58: 290-302

Descarries L, Watkins KC, Garcia S, Bosler O, Doucet G (1996). Dual character, asynaptic and synaptic, of the dopamine innervation in adult rat neostriatum: a quantitative autoradiographic and immunocytochemical analysis. J Comp Neurol 375: 167-186.

Deutch AY, Goldstein M, Baldino Jr F, Roth RH (1988). Telencephalic projections of the A8 dopamine cell group. Ann NY Acad Sci 537: 27-50.

Dobi A, Morales M (2007). Dopaminergic neurons in the rat ventral tegmental area (VTA) receive glutamatergic inputs from local glutamatergic neurons. Soc Neurosci Abstr 916: 8.

Dommett E, Coizet V, Blaha CD, Martindale J, Lefebvre V, Walton N et al (2005). How visual stimuli activate dopaminergic neurons at short latency. Science 307: 1476-1479. This publication, along with the Coizet and Comoli papers, provides an essential link between sensory processes and DA neuron activation and has important implications for understanding phasic activation of DA neurons in reward-related processes.

Dubé L, Smith AD, Bolam JP (1988). Identification of synaptic terminals of thalamic or cortical origin in contact with distinct medium-size spiny neurons in the rat neostriatum. J Comp Neurol 267: 455-471.

Dumartin B, Caillé I, Gonon F, Bloch B (1998). Internalization of D1 dopamine receptor in striatal neurons in vivo as evidence of activation by dopamine agonists. J Neurosci 18: 1650-1661.

Everitt BJ, Belin D, Economidou D, Pelloux Y, Dalley JW, Robbins TW (2008). Review. Neural mechanisms underlying the vulnerability to develop compulsive drug-seeking habits and addiction. Philos Trans $R$ Soc London Ser B 363: 3125-3135.

Everitt BJ, Robbins TW (2005). Neural systems of reinforcement for drug addiction: from actions to habits to compulsion. Nat Neurosci 8: 1481-1489.

Fadel J, Zahm DS, Deutch AY (2002). Anatomical substrates of orexin-dopamine interactions: lateral hypothalamic projections to the ventral tegmental area. Neuroscience 111: 379-387.

Faleiro LJ, Jones S, Kauer JA (2003). Rapid AMPAR/NMDAR response to amphetamine: a detectable increase in AMPAR/NMDAR ratios in the ventral tegmental area is detectable after amphetamine injection. Ann NY Acad Sci 1003: 391-394.
Faleiro LJ, Jones S, Kauer JA (2004). Rapid synaptic plasticity of glutamatergic synapses on dopamine neurons in the ventral tegmental area in response to acute amphetamine injection. Neuropsychopharmacology 29: 2115-2125.

Fallon JH, Moore RY (1978). Catecholamine innervation of the basal forebrain: IV. Topography of the dopamine projection to the basal forebrain and neostriatum. J Comp Neurol 180: 545-580.

Fanselow MS (2000). Contextual fear, gestalt memories, and the hippocampus. Behav Brain Res 110: 73-81.

Ferreira JG, Del-Fava F, Hasue RH, Shammah-Lagnado SJ (2008). Organization of ventral tegmental area projections to the ventral tegmental area - nigral complex in the rat. Neuroscience 153: 196-213. This publication demonstrated that different subdivisions of the nigral-VTA complex are interconnected, most likely via non-DA cells.

Fields HL, Hjelmstad GO, Margolis EB, Nicola SM (2007). Ventral tegmental area neurons in learned appetitive behavior and positive reinforcement. Annu Rev Neurosci 30: 289-316.

Finch DM (1996). Neurophysiology of converging synaptic inputs from the rat prefrontal cortex, amygdala, midline thalamus, and hippocampal formation onto single neurons of the caudate/putamen and nucleus accumbens. Hippocampus 6: 495-512.

Flores G, Alquicer G, Silva-Gomez AB, Zaldivar G, Stewart J, Quirion R et al (2005). Alterations in dendritic morphology of prefrontal cortical and nucleus accumbens neurons in post-pubertal rats after neonatal excitotoxic lesions of the ventral hippocampus. Neuroscience 133: 463-470.

Floresco SB, Grace AA (2003). Gating of hippocampal-evoked activity in prefrontal cortical neurons by inputs from the mediodorsal thalamus and ventral tegmental area. J Neurosci 23: 3930-3943.

Floresco SB, Todd CL, Grace AA (2001). Glutamatergic afferents from the hippocampus to the nucleus accumbens regulate activity of the ventral tegmental area dopamine neurons. J Neurosci 21: 4915-4922.

Floresco SB, West AR, Ash B, Moore H, Grace AA (2003). Afferent modulation of dopamine neuron firing differentially regulates tonic and phasic dopamine transmission. Nat Neurosci 6: 968-973. This paper provided a physiological explanation for tonic and phasic DA transmission and how it is modulated by different afferent systems.

Ford CP, Mark GP, Williams JT (2006). Properties and opioid inhibition of mesolimbic dopamine neurons vary according to target location. J Neurosci 26: 2788-2797.

Forster GL, Blaha CD (2000). Laterodorsal tegmental stimulation elicits dopamine efflux in the rat nucleus accumbens by activation of acetylcholine and glutamate receptors in the ventral tegmental area. Eur J Neurosci 12: 3596-3604.

Frankle WG, Laruelle M, Haber SN (2006). Prefrontal cortical projections to the midbrain in primates: evidence for a sparse connection. Neuropsychopharmacology 31: 1627-1636.

Freeman AS, Meltzer LT, Bunney BS (1985). Firing properties of substantia nigra dopaminergic neurons in freely moving rats. Life Sci 36: 1983-1994.

French SJ, Hailstone JC, Totterdell S (2003). Basolateral amygdala efferents to the ventral subiculum preferentially innervate pyramidal cell dendritic spines. Brain Res 981: 160-167.

French SJ, Ritson GP, Hidaka S, Totterdell S (2005). Nucleus accumbens nitric oxide immunoreactive interneurons receive nitric oxide and ventral subicular afferents in rats. Neuroscience 135: 121-131.

French SJ, Totterdell S (2002). Hippocampal and prefrontal cortical inputs monosynaptically converge with individual projection neurons of the nucleus accumbens. J Comp Neurol 446: 151-165. This publication and the 2003 paper below provide the first definitive anatomical evidence for synaptic convergence of multiple cortical inputs onto the same NAc medium spiny neurons, supporting a complex integrative function of this system.

French SJ, Totterdell S (2003). Individual nucleus accumbens-projection neurons receive both basolateral amygdala and ventral subicular afferents in rats. Neuroscience 119: 19-31.

French SJ, Totterdell S (2004). Quantification of morphological differences in boutons from different afferent populations to the nucleus accumbens. Brain Res 1007: 167-177.

Fudge JL, Haber SN (2000). The central nucleus of the amygdala projection to dopamine subpopulations in primates. Neuroscience 97: 479-494.

Futami T, Takakusaki K, Kitai S (1995). Glutamatergic and cholinergic inputs from the pedunculopontine tegmental nucleus to dopamine neurons in the substantia nigra pars compacta. Neurosci Res Supp/ 21: 331-342.

Garzón M, Vaughan RA, Uhl GR, Kuhar MJ, Pickel VM (1999). Cholinergic axon terminals in the ventral tegmental area target a subpopulation of neurons expressing low levels of the dopamine transporter. J Comp Neurol 410: 197-210.

Gaykema RP, Záborszky L (1996). Direct catecholaminergic-cholinergic interactions in the basal forebrain. II. Substantia nigra-ventral tegmental area projections to cholinergic neurons. J Comp Neuro/ 374: 555-577. 
Geisler S, Derst C, Veh RW, Zahm DS (2007). Glutamatergic afferents of the ventral tegmental area in the rat. $J$ Neurosci 27: 5730-5743. This seminal paper revealed that a substantial number of glutamate neurons, most previously uncharacterized, send excitatory projections to the VTA from many levels of the neural axis.

Geisler S, Marinelli M, Degarmo B, Becker ML, Freiman AJ, Beales M et al (2008). Prominent activation of brainstem and pallidal afferents of the ventral tegmental area by cocaine. Neuropsychopharmacology 33: 2688-2700.

Geisler S, Zahm DS (2005). Afferents of the ventral tegmental area in the ratanatomical substratum for integrative functions. J Comp Neurol 490: 270-294. This paper revealed that the VTA integrates convergent information from an interconnected network of cells comprising the reticular (isodendritic) core of the brain.

Geisler S, Zahm DS (2006). Neurotensin afferents of the ventral tegmental area in the rat: [1] re-examination of their origins and [2] responses to acute psychostimulant and antipsychotic drug administration. Eur J Neurosci 24: 116-134.

Georges F, Aston-Jones G (2002). Activation of ventral tegmental area cells by the bed nucleus of the stria terminalis: a novel excitatory amino acid input to midbrain dopamine neurons. J Neurosci 22: 5173-5187.

Gerfen CR (1992). The neostriatal mosaic: multiple levels of compartmental organization in the basal ganglia. Annu Rev Neurosci 15: 285-320.

Gerfen CR, Engber TM, Mahan LC, Susel Z, Chase TN, Monsma FJ et al (1990). D1 and D2 dopamine receptor regulated gene expression of striatonigral and striatopallidal neurons. Science 250: 1429-1432.

Gervais J, Rouillard C (2000). Dorsal raphe stimulation differentially modulates dopaminergic neurons in the ventral tegmental area and substantia nigra. Synapse 35: 281-291.

Gonzales C, Chesselet MF (1990). Amygdalonigral pathway: an anterograde study in the rat with Phaseolus vulgaris leucoagglutinin (PHA-L). J Comp Neurol 297: 182-200.

Goto Y, Grace AA (2005a). Dopamine-dependent interactions between limbic and prefrontal cortical plasticity in the nucleus accumbens: disruption by cocaine sensitization. Neuron 47: 255-266. This paper used in vivo recordings and drug administration to demonstrate how changes in synaptic plasticity induced by cocaine can translate into behavioral alterations, providing an important insight into how drug-induced alterations in circuitry can lead to pathological responses.

Goto Y, Grace AA (2005b). Dopaminergic modulation of limbic and cortical drive of nucleus accumbens in goal-directed behavior. Nat Neurosci 8: 805-812.

Goto Y, Grace AA (2008). Limbic and cortical information processing in the nucleus accumbens. Trends Neurosci 31: 552-558.

Goto Y, O'Donnell P (2002). Timing-dependent limbic-motor synaptic integration in the nucleus accumbens. Proce Natl Acad Sci 99: 13189-13193.

Grace AA (1991). Phasic vs tonic dopamine release and the modulation of dopamine system responsivity: a hypothesis for the etiology of schizophrenia. Neuroscience 41: 1-24. This paper provided the first accounting of phasic $v s$ tonic modes of DA transmission and how they can differentially signal postsynaptic structures.

Grace AA, Bunney BS (1979). Paradoxical GABA excitation of nigral dopaminergic cells: indirect mediation through reticulata inhibitory neurons. Eur $J$ Pharmacol 59: 211-218.

Grace AA, Bunney BS (1983). Intracellular and extracellular electrophysiology of nigral dopaminergic neurons. 1. Identification and characterization. Neuroscience 10: 301-315

Grace AA, Bunney BS (1984a). The control of firing pattern in nigral dopamine neurons: burst firing. J Neurosci 4: 2877-2890.

Grace AA, Bunney BS (1984b). The control of firing pattern in nigral dopamine neurons: single spike firing. J Neurosci 4: 2866-2876.

Grace AA, Bunney BS (1985). Opposing effects of striatonigral feedback pathways on midbrain dopamine cell activity. Brain Res 333: 271-284.

Grace AA, Floresco SB, Goto Y, Lodge DJ (2007). Regulation of firing of dopaminergic neurons and control of goal-directed behaviors. Trends Neurosci 30: 220-227

Grace AA, Onn S (1989). Morphology and electrophysiological properties of immunocytochemically identified rat dopamine neurons recorded in vitro. J Neurosci 9: 3463-3481.

Grenhoff J, North RA, Johnson SW (1995). Alpha 1-adrenergic effects on dopamine neurons recorded intracellularly in the rat midbrain slice. Eur $J$ Neurosci 7: 1707-1713.

Groenewegen HJ (1988). Organization of the afferent connections of the mediodorsal thalamic nucleus in the rat, related to the mediodorsal-prefrontal topography. Neuroscience 24: 379-431.

Groenewegen HJ, Berendse HW, Haber SN (1993). Organization of the output of the ventral striatopallidal system in the rat: ventral pallidal efferents. Neuroscience 57: $113-142$
Groenewegen HJ, Russchen FT (1984). Organization of the efferent projections of the nucleus accumbens to pallidal, hypothalamic, and mesencephalic structures: a tracing and immunohistochemical study in the cat. J Comp Neurol 223 347-367.

Groenewegen HJ, Vermeulen-Van der Zee E, te Kortschot A, Witter MP (1987). Organization of the projections from the subiculum to the ventral striatum in the rat. A study using anterograde transport of Phaseolus vulgais leucoagglutinin. Neuroscience 23: 103-120.

Groenewegen HJ, Wright Cl, Beijer AV (1996). The nucleus accumbens: gateway for limbic structures to reach the motor system? Prog Brain Res 107: 485-511.

Groenewegen HJ, Wright Cl, Beijer AV, Voorn P (1999). Convergence and segregation of ventral striatal inputs and outputs. Ann NY Acad Sci 877: 49-63.

Gruber AJ, Hussain RJ, O'Donnell P (2009a). The nucleus accumbens: a switchboard for goal-directed behaviors. PLOS ONE 4: e5062. This paper used in vivo recordings in PFC, hippocampus, and NAc to show that alterations in synchrony of rhythmic activity occur in concert with changes in behavioral contingencies.

Gruber AJ, Powell EM, O'Donnell P (2009b). Cortically activated interneurons shape spatial aspects of cortico-accumbens processing. J Neurophysiol 101 1876-1882.

Guiard BP, El Mansari M, Blier P (2008). Cross-talk between dopaminergic and noradrenergic systems in the rat ventral tegmental area, locus ceruleus, and dorsal hippocampus. Mol Pharmacol 74: 1463-1475.

Haber SN, Fudge JL, McFarland NR (2000). Striatonigrostriatal pathways in primates form an ascending spiral from the shell to the dorsolateral striatum. J Neurosci 20: 2369-2382. This paper reconceptualized the model of 'parallel loops' running through basal ganglia circuitry to one of an ascending medial to lateral spiral that ultimately communicates limbic information to motor control and cognitive function.

Haber SN, Lynd E, Klein C, Groenewegen HJ (1990). Topographic organization of the ventral striatal efferent projections in the rhesus monkey: an anterograde tracing study. J Comp Neurol 293: 282-298.

Haber SN, Ryoo H, Cox C, Lu W (1995). Subsets of midbrain dopaminergic neurons in monkeys are distinguished by different levels of mRNA for the dopamine transporter: comparison with the mRNA for the $\mathrm{D}_{2}$ receptor, tyrosine hydroxylase and calbindin immunoreactivity. J Comp Neurol 362: 400-410.

Hariri AR, Mattay VS, Tessitore A, Fera F, Weinberger DR (2003). Neocortical modulation of the amygdala response to fearful stimuli. Biol Psychiatry 53: 494-501.

Harris GC, Wimmer M, Aston-Jones G (2005). A role for lateral hypothalamic orexin neurons in reward seeking. Nature 437: 556-559.

Hasue RH, Shammah-Lagnado SJ (2002). Origin of the dopaminergic innervation of the central extended amygdala and accumbens shell: a combined retrograde tracing and immunohistochemical study in the rat. J Comp Neurol 454: 15-33.

Heimer L, Zahm DS, Churchill L, Kalivas PW, Wohltmann C (1991). Specificity in the projection patterns of accumbal core and shell in the rat. Neuroscience 41 89-125. This important paper detailing the projections from the NAc core and shell to relatively segregated regions within the VP, basal forebrain, hypothalamus and midbrain, established the striatal character of both the core and shell subdivisions and highlighted the additional alignment of the shell with the extended amygdala.

Herkenham M, Nauta WJ (1979). Efferent connections of the habenular nuclei in the rat. J Comp Neurol 187: 19-47.

Herman JP, Mueller NK (2006). Role of the ventral subiculum in stress integration. Behav Brain Res 174: 215-224. This paper brought to the forefront research demonstrating that the ventral subiculum has a central and important role in the regulation of the stress response.

Hersch SM, Ciliax BJ, Gutekunst CA, Rees HD, Heilman CJ, Yung KKL et al (1995). Electron microscopic analysis of D1 and D2 dopamine receptor proteins in the dorsal striatum and their synaptic relationships with motor corticostriatal afferents. J Neurosci 15: 5222-5237.

Hervé D, Pickel VM, Joh TH, Beaudet A (1987). Serotonin axon terminals in the ventral tegmental area of the rat: fine structure and synaptic input to dopaminergic neurons. Brain Res 435: 71-83.

Herzog E, Bellenchi GC, Gras C, Bernard V, Ravassard P, Bedet C et al (2001). The existence of a second vesicular glutamate transporter specifies subpopulations of glutamatergic neurons. J Neurosci 21: RC181.

Hidaka S, Totterdell S (2001). Ultrastructural features of the nitric oxide synthasecontaining interneurons in the nucleus accumbens and their relationship with tyrosine hydroxylase-containing terminals. J Comp Neurol 431: 139-154.

Hikosaka O, Sesack SR, Lecourtier L, Shepard PD (2008). Habenula: crossroad between the basal ganglia and the limbic system. J Neurosci 28: 11825-11829.

Hollerman JR, Schultz W (1998). Dopamine neurons report an error in the temporal prediction of reward during learning. Nat Neurosci 1: 304-309. This paper, which formed the basis of many computational models of DA system function, was the first manuscript to demonstrate that DA neuron activity shows attenuation 
when animals are presented with the absence of a reward, or an error in reward prediction.

Horvitz JC (2000). Mesolimbocortical and nigrostriatal dopamine responses to salient non-reward events. Neuroscience 96: 651-656.

Huey ED, Zahn R, Krueger F, Moll J, Kapogiannis D, Wassermann EM et al (2008). A psychological and neuroanatomical model of obsessive-compulsive disorder. J Neuropsychiatry Clin Neurosci 20: 390-408.

Hur EE, Zaborszky L (2005). Vglut2 afferents to the medial prefrontal and primary somatosensory cortices: a combined retrograde tracing in situ hybridization. J Comp Neurol 483: 351-373.

Hussain Z, Johnson LR, Totterdell S (1996). A light and electron microscopic study of NADPH-diaphorase-, calretinin- and parvalbumin-containing neurons in the rat nucleus accumbens. J Chem Neuroanat 10: 19-39.

Hyman SE, Malenka RC, Nestler EJ (2006). Neural mechanisms of addiction: the role of reward-related learning and memory. Annu Rev Neurosci 29: 565-598.

Ikemoto S (2007). Dopamine reward circuitry: two projection systems from the ventral midbrain to the nucleus accumbens-olfactory tubercle complex. Brain Res Rev 56: 27-78.

Ishikawa A, Ambroggi F, Nicola SM, Fields HL (2008). Contributions of the amygdala and medial prefrontal cortex to incentive cue responding. Neuroscience 155: 573-584.

Ito R, Dalley JW, Robbins TW, Everitt BJ (2002). Dopamine release in the dorsal striatum during cocaine-seeking behavior under the control of a drug-associated cue. J Neurosci 22: 6247-6253.

Ito R, Robbins TW, Pennartz CM, Everitt BJ (2008). Functional interaction between the hippocampus and nucleus accumbens shell is necessary for the acquisition of appetitive spatial context conditioning. J Neurosci 28: 6950-6959. This paper provided an important link between understanding brain circuitry and appetitive conditioning.

Izzo PN, Bolam JP (1988). Cholinergic synaptic input to different parts of spiny striatonigral neurons in the rat. J Comp Neurol 269: 219-234.

Jarrard LE (1995). What does the hippocampus really do? Behav Brain Res 71: 1-10. Jay TM, Thierry AM, Wiklund L, Glowinski J (1992). Excitatory amino acid pathway from the hippocampus to the prefrontal cortex. Contribution of AMPA receptors in hippocampo-prefrontal cortex transmission. Eur J Neurosci 4: 1285-1295.

Jhou TC, Fields HL, Baxter MG, Saper CB, Holland PC (2009a). The rostromedial tegmental nucleus (RMTg), a GABAergic afferent to midbrain dopamine neurons, encodes aversive stimuli and inhibits motor responses. Neuron 61: 786-800.

Jhou TC, Gallagher M (2007). Paramedian raphe neurons that project to midbrain dopamine neurons are activated by aversive stimuli. Soc Neurosci Abstr 425: 5.

Jhou TC, Geisler S, Marinelli M, Degarmo BA, Zahm DS (2009b). The mesopontine rostromedial tegmental nucleus: a structure targeted by the lateral habenula that projects to the ventral tegmental area of Tsai and substantia nigra compacta. $J$ Comp Neurol 513: 566-596. This noteworthy paper presented extensive evidence that a previously unappreciated area of the brainstem serves as an essential inhibitory gateway to midbrain DA neurons.

Ji H, Shepard PD (2007). Lateral habenula stimulation inhibits rat midbrain dopamine neurons through a $\mathrm{GABA}(\mathrm{A})$ receptor-mediated mechanism. J Neurosci 27: 6923-6930.

Johnson LR, Aylward RLM, Hussain Z, Totterdell S (1994). Input from the amygdala to the rat nucleus accumbens: its relationship with tyrosine hydroxylase immunoreactivity and identified neurons. Neuroscience 61: 851-865.

Johnson SW, North RA (1992). Two types of neurone in the rat ventral tegmental area and their synaptic inputs. J Physiol 450: 455-468.

Jongen-Rêlo AL, Groenewegen HJ, Voorn P (1993). Evidence for a multicompartmental histochemical organization of the nucleus accumbens in the rat. J Comp Neurol 337: 267-276.

Jongen-Rêlo AL, Voorn P, Groenewegen HJ (1994). Immunohistochemical characterization of the shell and core territories of the nucleus accumbens in the rat. Eur J Neurosci 6: 1255-1264.

Kalivas PW (1995). Interactions between dopamine and excitatory amino acids in behavioral sensitization to psychostimulants. Drug Alcohol Depend 37: 95-100.

Kalivas PW, McFarland K (2003). Brain circuitry and the reinstatement of cocaineseeking behavior. Psychopharmacology 168: 44-56.

Kalivas PW, Stewart J (1991). Dopamine transmission in the initiation and expression of drug- and stress-induced sensitization of motor activity. Brain Res Rev 16: 223-244.

Kalivas PW, Volkow N, Seamans J (2005). Unmanageable motivation in addiction: a pathology in prefrontal-accumbens glutamate transmission. Neuron 45: 647-650. This paper provided a synthesis of data regarding how PFC glutamate projections to the NAc may underlie the behavioral deficits associated with addictive behavior.

Kaufling J, Veinante P, Pawlowski SA, Freund-Mercier M-J, Barrot M (2009). Afferents to the GABAergic tail of the ventral tegmental area in the rat. J Comp Neurol 513: 597-621.
Kawaguchi Y, Wilson CJ, Augood SJ, Emson PC (1995). Striatal interneurones: chemical, physiological and morphological characterization. Trends Neurosci 18: $527-535$.

Kawano M, Kawasaki A, Sakata-Haga H, Fukui Y, Kawano H, Nogami $\mathrm{H}$ et al (2006). Particular subpopulations of midbrain and hypothalamic dopamine neurons express vesicular glutamate transporter 2 in the rat brain. $J$ Comp Neurol 498: 581-592.

Kelley AE, Domesick VB (1982). The distribution of the projection from the hippocampal formation to the nucleus accumbens in the rat: an anterogradeand retrograde-horseradish peroxidase study. Neuroscience 7: 2321-2335.

Kelley AE, Domesick VB, Nauta WJH (1982). The amygdalostriatal projection in the rat-an anatomical study by anterograde and retrograde tracing methods. Neuroscience 7: 615-630.

Kelley AE, Stinus $L$ (1984). The distribution of the projection from the parataenial nucleus of the thalamus to the nucleus accumbens in the rat: an autoradiographic study. Exp Brain Res 54: 499-512.

Ketter TA (2008). Monotherapy vs combined treatment with second-generation antipsychotics in bipolar disorder. J Clin Psychiatry 69(Suppl 5): 9-15.

Kita H, Kitai ST (1990). Amygdaloid projections to the frontal cortex and the striatum in the rat. J Comp Neurol 298: 40-49.

Klitenick MA, Deutch AY, Churchill L, Kalivas PW (1992). Topography and functional role of dopaminergic projections from the ventral mesencephalic tegmentum to the ventral pallidum. Neuroscience 50: 371-386.

Koob GF (1992). Drugs of abuse: anatomy, pharmacology and function of reward pathways. Trends Pharmacol Sci 13: 177-184.

Korotkova TM, Sergeeva OA, Eriksson KS, Haas HL, Brown RE (2003). Excitation of ventral tegmental area dopaminergic and nondopaminergic neurons by orexins/ hypocretins. J Neurosci 23: 7-11.

Lammel S, Hetzel A, Hackel O, Jones I, Liss B, Roeper J (2008). Unique properties of mesoprefrontal neurons within a dual mesocorticolimbic dopamine system. Neuron 57: 760-773. This is the first paper providing evidence for functionally defined subclasses of midbrain dopamine neurons in the mouse brain.

Lapper SR, Bolam JP (1992). Input from the frontal cortex and the parafascicular nucleus to cholinergic interneurons in the dorsal striatum of the rat. Neuroscience 51: 533-545.

Lapper SR, Smith Y, Sadikot AF, Parent A, Bolam JP (1992). Cortical input to parvalbumin-immunoreactive neurones in the putamen of the squirrel monkey. Brain Res 580: 215-224.

Lavin A, Grace AA (1994). Modulation of dorsal thalamic cell activity by the ventral pallidum: its role in the regulation of thalamocortical activity by the basal ganglia. Synapse 18: 104-127.

Lavin A, Nogueira L, Lapish CC, Wightman RM, Phillips PE, Seamans JK (2005). Mesocortical dopamine neurons operate in distinct temporal domains using multimodal signaling. J Neurosci 25: 5013-5023.

Laviolette SR, Grace AA (2006). The roles of cannabinoid and dopamine receptor systems in neural emotional learning circuits: implications for schizophrenia and addiction. Cell Mol Life Sci 63: 1597-1613.

Laviolette SR, Lipski WJ, Grace AA (2005). A subpopulation of neurons in the medial prefrontal cortex encodes emotional learning with burst and frequency codes through a dopamine D4 receptor-dependent basolateral amygdala input. $\checkmark$ Neurosci 25: 6066-6075. This manuscript was the first to demonstrate the importance of the PFC ( $v$ s the amygdala) in the expression of behavioral learning, and refocused attention on the role of D4 receptors on interneurons in controlling this behavioral output.

Lavoie B, Parent A (1994). Pedunculopontine nucleus in the squirrel monkey: cholinergic and glutamatergic projections to the substantia nigra. J Comp Neurol 344: 232-241.

Le Moine C, Bloch B (1995). D1 and D2 dopamine receptor gene expression in the rat striatum: sensitive cRNA probes demonstrate prominent segregation of D1 and D2 mRNAs in distinct neuronal populations of the dorsal and ventral striatum. J Comp Neurol 355: 418-426.

Le Moine C, Bloch B (1996). Expression of the D3 dopamine receptor in peptidergic neurons of the nucleus accumbens: comparison with the D1 and D2 dopamine receptors. Neuroscience 73: 131-143.

LeDoux JE (2000). Emotion circuits in the brain. Annu Rev Neurosci 23: 155-184.

Lee KW, Kim Y, Kim AM, Helmin K, Nairn AC, Greengard P (2006). Cocaine-induced dendritic spine formation in D1 and D2 dopamine receptor-containing medium spiny neurons in nucleus accumbens. Proc Natl Acad Sci 103: 3399-3404.

Lewis DA, Sesack SR (1997). Dopamine systems in the primate brain. In: Bloom FE, Björklund A, Hökfelt T (eds). Handbook of Chemical Neuroanatomy, The Primate Nervous System, Part I. Elsevier: Amsterdam. pp 261-373.

Lin YJ, Greif GJ, Freedman JE (1996). Permeation and block of dopaminemodulated potassium channels on rat striatal neurons by cesium and barium ions. J Neurophysiol 76: 1413-1422. 
Liprando LA, Miner LH, Blakely RD, Lewis DA, Sesack SR (2004). Ultrastructural interactions between terminals expressing the norepinephrine transporter and dopamine neurons in the rat and monkey ventral tegmental area. Synapse 52: 233-244.

Lipski WJ, Grace AA (2008). Neurons in the ventral subiculum are activated by noxious stimuli and are modulated by noradrenergic afferents. Soc Neurosci Abstr 195: 1.

Lisman JE, Grace AA (2005). The hippocampal-VTA loop: controlling the entry of information into long-term memory. Neuron 46: 703-713.

Lodge DJ, Grace AA (2006a). The hippocampus modulates dopamine neuron responsivity by regulating the intensity of phasic neuron activation. Neuropsychopharmacology 31: 1356-1361. The data in this paper demonstrated independent pathways regulating DA neuron populations: one supplying the 'signal' that drives phasic firing and one that provides the 'gain' of the signal based on the environmental context.

Lodge DJ, Grace AA (2006b). The laterodorsal tegmentum is essential for burst firing of ventral tegmental area dopamine neurons. Proc Natl Acad Sci 103: 5167-5172.

Lodge DJ, Grace AA (2008). Amphetamine activation of hippocampal drive of mesolimbic dopamine neurons: a mechanism of behavioral sensitization. J Neurosc 28: 7876-7882. This paper showed that alteration in the DA 'gain,' i.e. the number of DA neurons firing, is disrupted by amphetamine sensitization, thus providing an electrophysiological link between contextdependent sensitization and DA neuron activity.

Lokwan SJ, Overton PG, Berry MS, Clark D (1999). Stimulation of the pedunculopontine tegmental nucleus in the rat produces burst firing in A9 dopaminergic neurons. Neuroscience 92: 245-254.

Loughlin SE, Fallon JH (1983). Dopaminergic and non-dopaminergic projections to amygdala from substantia nigra and ventral tegmental area. Brain Res 262: 334-338.

Lu X-Y, Churchill L, Kalivas PW (1997). Expression of $D_{1}$ receptor mRNA in projections from the forebrain to the ventral tegmental area. Synapse 25: 205-214.

Lu X-Y, Ghasemzadeh MB, Kalivas PW (1998). Expression of D1 receptor, D2 receptor, substance $\mathrm{P}$ and enkephalin messenger RNAs in the neurons projecting from the nucleus accumbens. Neuroscience 82: 767-780.

Mallet N, Le Moine C, Charpier S, Gonon F (2005). Feedforward inhibition of projection neurons by fast-spiking GABA interneurons in the rat striatum in vivo. J Neurosci 25: 3857-3869.

Maren S (1999). Neurotoxic or electrolytic lesions of the ventral subiculum produce deficits in the acquisition and expression of Pavlovian fear conditioning in rats. Behav Neurosci 113: 283-290.

Maren S, Quirk GJ (2004). Neuronal signalling of fear memory. Nat Rev Neurosci 5 844-852.

Margolis EB, Mitchell JM, Ishikawa J, Hjelmstad GO, Fields HL (2008). Midbrain dopamine neurons: projection target determines action potential duration and dopamine D(2) receptor inhibition. J Neurosci 28: 8908-8913.

Martin G, Fabre V, Siggins GR, de Lecea L (2002). Interaction of the hypocretins with neurotransmitters in the nucleus accumbens. Regul Pept 104: 111-117.

Martin LJ, Hadfield MG, Dellovade TL, Price DL (1991). The striatal mosaic in primates: patterns of neuropeptide immunoreactivity differentiate the ventral striatum from the dorsal striatum. Neuroscience 43: 397-417.

Martone ME, Armstrong DM, Young SJ, Groves PM (1992). Ultrastructural examination of enkephalin and substance $P$ input to cholinergic neurons within the rat neostriatum. Brain Res 594: 253-262.

Mathew SJ (2008). Treatment-resistant depression: recent developments and future directions. Depress Anxiety 25: 989-992.

Matsumoto M, Hikosaka O (2007). Lateral habenula as a source of negative reward signals in dopamine neurons. Nature 447: 1111-1115. In this manuscript, the authors provided evidence suggesting that the habenula mediates an important inhibitory regulation of DA neurons that may signal errors in reward expectancy.

McDonald AJ (1991). Topographical organization of amygdaloid projections to the caudatoputamen, nucleus accumbens, and related striatal-like areas of the rat brain. Neuroscience 44: 15-33.

McGinty VB, Grace AA (2008). Selective activation of medial prefrontal-toaccumbens projection neurons by amygdala stimulation and Pavlovian conditioned stimuli. Cereb Cortex 18: 1961-1972.

McGinty VB, Grace AA (2009). Timing-dependent regulation of evoked spiking in nucleus accumbens neurons by integration of limbic and prefrontal cortical inputs. J Neurophysiol 101: 1823-1835.

Mejías-Aponte CA, Drouin C, Aston-Jones G (2009). Adrenergic and noradrenergic innervation of the midbrain ventral tegmental area and retrorubral field: prominent inputs from medullary homeostatic centers. J Neurosci 29: 3613-3626.

Melchitzky DS, Erickson SL, Lewis DA (2006). Dopamine innervation of the monkey mediodorsal thalamus: location of projection neurons and ultrastructural characteristics of axon terminals. Neuroscience 143: 1021-1030.
Mena-Segovia J, Winn P, Bolam JP (2008). Cholinergic modulation of midbrain dopaminergic systems. Brain Res Rev 58: 265-271.

Meredith GE (1999). The synaptic framework for chemical signaling in nucleus accumbens. Ann NY Acad Sci 877: 140-156.

Meredith GE, Agolia R, Arts MP, Groenewegen HJ, Zahm DS (1992). Morphological differences between projection neurons of the core and shell in the nucleus accumbens of the rat. Neuroscience 50: 149-162.

Meredith GE, Pattiselanno A, Groenewegen HJ, Haber SN (1996). Shell and core in monkey and human nucleus accumbens identified with antibodies to calbindin$\mathrm{D}_{28 \mathrm{k}}$. J Comp Neurol 365: 628-639.

Meredith GE, Wouterlood FG (1990). Hippocampal and midline thalamic fibers and terminals in relation to the choline acetyltransferase-immunoreactive neurons in nucleus accumbens of the rat: a light and electron microscopic study. J Comp Neurol 296: 204-221.

Meredith GE, Wouterlood FG, Pattiselanno A (1990). Hippocampal fibers make synaptic contacts with glutamate decarboxylase-immunoreactive neurons in the rat nucleus accumbens. Brain Res 513: 329-334.

Mink JW (1996). The basal ganglia: focused selection and inhibition of competing motor programs. Prog Neurobiol 50: 381-425.

Mogenson GJ, Jones DL, Yim CY (1980). From motivation to action: functional interface between the limbic system and the motor system. Prog Neurobiol 14 69-97. This landmark paper defined the essential role of the NAc.

Montague PR, Hyman SE, Cohen JD (2004). Computational roles for dopamine in behavioural control. Nature 431: 760-767.

Montaron MF, Deniau JM, Menetrey A, Glowinski J, Thierry AM (1996). Prefrontal cortex inputs of the nucleus accumbens-nigro-thalamic circuit. Neuroscience 71: 371-382

Moore H, West AR, Grace AA (1999). The regulation of forebrain dopamine transmission: relevance to the pathophysiology and psychopathology of schizophrenia. Biol Psychiatry 46: 40-55.

Moss J, Bolam JP (2008). A dopaminergic axon lattice in the striatum and its relationship with cortical and thalamic terminals. J Neurosci 28: 11221-11230.

Mugnaini E, Oertel WH (1985). An atlas of the distribution of GABAergic neurons and terminals in the rat CNS as revealed by GAD immunocytochemistry. In: Björklund A, Hökfelt T (eds). Handbook of Chemical Neuroanatomy. Vol 4: GABA and Neuropeptides in the CNS, Part I. Elsevier BV: Amsterdam. pp 436-608.

Nair-Roberts RG, Chatelain-Badie SD, Benson E, White-Cooper H, Bolam JP, Ungless MA (2008). Stereological estimates of dopaminergic, GABAergic and glutamatergic neurons in the ventral tegmental area, substantia nigra and retrorubral field in the rat. Neuroscience 152: 1024-1031.

Nauta WJ, Smith GP, Faull RL, Domesick VB (1978). Efferent connections and nigral afferents of the nucleus accumbens septi in the rat. Neuroscience 3: 385-401.

Nicola SM, Surmeier J, Malenka RC (2000). Dopaminergic modulation of neuronal excitability in the striatum and nucleus accumbens. Annu Rev of Neurosci 23: 185-215.

Nugent FS, Kauer JA (2008). LTP of GABAergic synapses in the ventral tegmental area and beyond. J Physiol 586: 1487-1493.

O'Donnell P (2003). Dopamine gating of forebrain neural ensembles. Eur J Neurosci 17: 429-435.

O'Donnell P, Grace AA (1993). Physiological and morphological properties of accumbens core and shell neurons recorded in vitro. Synapse 13: 135-160.

O'Donnell P, Grace AA (1994). Tonic $D_{2}$-mediated attenuation of cortical excitation in nucleus accumbens neurons recorded in vitro. Brain Res 634: 105-112.

O'Donnell P, Grace AA (1995). Synaptic interactions among excitatory afferents to nucleus accumbens neurons: hippocampal gating of prefrontal cortical input. J Neurosci 15: 3622-3639. This study provided electrophysiological evidence for convergence of cortical inputs onto NAc neurons and further demonstrated that the ventral hippocampus drives 'up' states in NAc cells, thus functionally gating information flow in this region.

O'Donnell P, Grace AA (1996). Dopaminergic reduction of excitability in nucleus accumbens neurons recorded in vitro. Neuropsychopharmacology 15: 87-97.

O'Donnell P, Grace AA (1998). Phencyclidine interferes with the hippocampal gating of nucleus accumbens neuronal activity in vivo. Neuroscience 87: 823-830.

O'Donnell P, Lavin A, Enquist LW, Grace AA, Card JP (1997). Interconnected parallel circuits between rat nucleus accumbens and thalamus revealed by retrograde transynaptic transport of pseudorabies virus. J Neurosci 17: 2143-2167.

O'Mara S (2005). The subiculum: what it does, what it might do, and what neuroanatomy has yet to tell us. J Anat 207: 271-282.

Oakman SC, Faris PL, Kerr PE, Cozzari C, Hartman BK (1995). Distribution of pontomesencephalic cholinergic neurons projecting to substantia nigra differs significantly from those projecting to ventral tegmental area. J Neurosci 15 5859-5869.

Oleskevich S, Descarries L, Lacaille JC (1989). Quantified distribution of the noradrenaline innervation in the hippocampus of adult rat. J Neurosci 9: 3803-3815. 
Olson VG, Nestler EJ (2007). Topographical organization of GABAergic neurons within the ventral tegmental area of the rat. Synapse 61: 87-95.

Omelchenko N, Sesack SR (2005). Laterodorsal tegmental projections to identified cell populations in the rat ventral tegmental area. J Comp Neurol 483: 217-235.

Omelchenko N, Sesack SR (2006). Cholinergic axons in the rat ventral tegmental area synapse preferentially onto mesoaccumbens dopamine neurons. J Comp Neurol 494: 863-875.

Omelchenko N, Sesack SR (2007). Glutamate synaptic inputs to ventral tegmental area neurons in the rat derive primarily from subcortical sources. Neuroscience 146: $1259-1274$

Omelchenko N, Sesack SR (2009). Ultrastructural analysis of local collaterals of rat ventral tegmental area neurons: GABA phenotype and synapses onto dopamine and GABA cells. Synapse 63: 895-906.

Onn SP, Grace AA (1994). Dye coupling between rat striatal neurons recorded in vivo: compartmental organization and modulation by dopamine. J Neurophysiol 71: 1917-1934. This paper demonstrated that gap junction conductance in the striatum is functionally regulated, and may be implicated in DA-related disorders.

Onn SP, West AR, Grace AA (2000). Dopamine-mediated regulation of striatal neuronal and network interactions. Trends Neurosci 23: S48-S56.

Otake K, Nakamura Y (1998). Single midline thalamic neurons projecting to both the ventral striatum and the prefrontal cortex in the rat. Neuroscience 86: 635-649.

Pacchioni AM, Gioino G, Assis A, Cancela LM (2002). A single exposure to restraint stress induces behavioral and neurochemical sensitization to stimulating effects of amphetamine: involvement of NMDA receptors. Ann NY Acad Sci 965: 233-246.

Pennartz CM, Groenewegen HJ, Lopes da Silva FH (1994). The nucleus accumbens as a complex of functionally distinct neuronal ensembles: an integration of behavioural, electrophysiological and anatomical data. Prog Neurobiol 42: 719-761.

Perrotti LI, Bolanos CA, Choi KH, Russo SJ, Edwards S, Ulery PG et al (2005). DeltaFosB accumulates in a GABAergic cell population in the posterior tail of the ventral tegmental area after psychostimulant treatment. Eur J Neurosci 21: 2817-2824.

Pessia M, Jiang ZG, North RA, Johnson SW (1994). Actions of 5-hydroxytryptamine on ventral tegmental area neurons of the rat in vitro. Brain Res 654: 324-330.

Peyron C, Tighe DK, Van Den Pol AN, de Lecea L, Heller HC, Sutcliffe JG et al (1998). Neurons containing hypocretin (orexin) project to multiple neuronal systems. J Neurosci 18: 9996-10015.

Phillipson OT (1979a). Afferent projections to the ventral tegmental area of Tsai and interfascicular nucleus: a horseradish peroxidase study in the rat. J Comp Neurol 187: $117-144$

Phillipson OT (1979b). A Golgi study of the ventral tegmental area of Tsai and interfascicular nucleus in the rat. J Comp Neurol 187: 99-116.

Pickel VM, Chan J (1990). Spiny neurons lacking choline acetyltransferase immunoreactivity are major targets of cholinergic and catecholaminergic terminals in rat striatum. J Neurosci Res 25: 263-280.

Pickel VM, Chan J, Sesack SR (1993). Cellular substrates for interactions between dynorphin terminals and dopamine dendrites in rat ventral tegmental area and substantia nigra. Brain Res 602: 275-289.

Pickel VM, Towle A, Joh TH, Chan J (1988). Gamma-aminobutyric acid in the medial rat nucleus accumbens: ultrastructural localization in neurons receiving monosynaptic input from catecholaminergic afferents. J Comp Neurol 272: $1-14$.

Pinto A, Jankowski M, Sesack SR (2003). Projections from the paraventricular nucleus of the thalamus to the rat prefrontal cortex and nucleus accumbens shell: ultrastructural characteristics and spatial relationships with dopamine afferents. J Comp Neurol 459: 142-155. This paper provided the first evidence that thalamic as well as cortical axons exhibit synaptic convergence with DA afferents onto the same distal dendrites of medium spiny neurons in the NAc.

Pitkänen A, Pikkarainen M, Nurminen N, Ylinen A (2000). Reciprocal connections between the amygdala and the hippocampal formation, perirhinal cortex, and postrhinal cortex in rat. A review. Ann NY Acad Sci 911: 369-391.

Porrino LJ, Lyons D, Smith HR, Daunais JB, Nader MA (2004). Cocaine selfadministration produces a progressive involvement of limbic, association, and sensorimotor striatal domains. J Neurosci 24: 3554-3562.

Post RM, Rose H (1976). Increasing effects of repetitive cocaine administration in the rat. Nature 260: 731-732. This paper demonstrated the phenomenon of cocaine sensitization, i.e. the increasing behavioral actions (reverse tolerance) observed with repeated cocaine administration.

Price JL, Amaral DG (1981). An autoradiographic study of the projections of the central nucleus of the monkey amygdala. J Neurosci 1: 1242-1259.

Ramón-Moliner E, Nauta WJH (1966). The isodendritic core of the brain stem. J Comp Neurol 126: 311-335.
Redgrave P, Gurney K, Reynolds $\mathrm{J}$ (2008). What is reinforced by phasic dopamine signals? Brain Res Rev 58: 322-339.

Redgrave P, Prescott TJ, Gurney K (1999). The basal ganglia: a vertebrate solution to the selection problem? Neuroscience 89: 1009-1023.

Reynolds SM, Geisler S, Berod A, Zahm DS (2006). Neurotensin antagonist acutely and robustly attenuates locomotion that accompanies stimulation of a neurotensin-containing pathway from rostrobasal forebrain to the ventral tegmental area. Eur J Neurosci 24: 188-196.

Reynolds SM, Zahm DS (2005). Specificity in the projections of prefrontal and insular cortex to ventral striatopallidum and the extended amygdala. J Neurosci 25: 11757-11767.

Robbins TW, Ersche KD, Everitt BJ (2008). Drug addiction and the memory systems of the brain. Ann NY Acad Sci 1141: 1-21.

Robbins TW, Everitt BJ (2002). Limbic-striatal memory systems and drug addiction. Neurobiol Learn Mem 78: 625-636.

Robertson GS, Jian M (1995). D1 and D2 dopamine receptors differentially increase Fos-like immunoreactivity in accumbal projections to the ventral pallidum and midbrain. Neuroscience 64: 1019-1034.

Robinson TE, Kolb B (2004). Structural plasticity associated with exposure to drugs of abuse. Neuropharmacology 47(Suppl 1): 33-46.

Rodaros D, Caruana DA, Amir S, Stewart J (2007). Corticotropin-releasing factor projections from limbic forebrain and paraventricular nucleus of the hypothalamus to the region of the ventral tegmental area. Neuroscience 150: 8-13.

Rodd-Henricks ZA, McKinzie DL, Li TK, Murphy JM, McBride WJ (2002). Cocaine is self-administered into the shell but not the core of the nucleus accumbens of Wistar rats. J Pharmacol Exp Ther 303: 1216-1226.

Rodríguez A, González-Hernández T (1999). Electrophysiological and morphological evidence for a GABAergic nigrostriatal pathway. J Neurosci 19: 4682-4694.

Rosenkranz JA, Grace AA (2001). Dopamine attenuates prefrontal cortical suppression of sensory inputs to the basolateral amygdala of rats. $J$ Neurosci 21: 4090-4103.

Rosenkranz JA, Grace AA (2002). Cellular mechanisms of infralimbic and prelimbic prefrontal cortical inhibition and dopaminergic modulation of basolateral amygdala neurons in vivo. J Neurosci 22: 324-327.

Saka E, Goodrich C, Harlan P, Madras BK, Graybiel AM (2004). Repetitive behaviors in monkeys are linked to specific striatal activation patterns. J Neurosci 24: 7557-7565.

Sánchez-González MA, García-Cabezas MA, Rico B, Cavada C (2005). The primate thalamus is a key target for brain dopamine. J Neurosci 25: 6076-6083.

Schilstrom B, Yaka R, Argilli E, Suvarna N, Schumann J, Chen BT et al (2006). Cocaine enhances NMDA receptor-mediated currents in ventral tegmental area cells via dopamine D5 receptor-dependent redistribution of NMDA receptors. J Neurosci 26: 8549-8558.

Schroeter S, Apparsundaram S, Wiley RG, Miner LAH, Sesack SR, Blakely RD (2000). Immunolocalization of the cocaine- and antidepressant sensitive L-norepinephrine transporter. J Comp Neurol 420: 211-232.

Schultz W (1998a). The phasic reward signal of primate dopamine neurons. Adv Pharmacol 42: 686-690.

Schultz W (1998b). Predictive reward signal of dopamine neurons. J Neurophysiol 80: $1-27$

Schultz W (2007). Behavioral dopamine signals. Trends Neurosci 30: 203-210.

Schultz W, Dickinson A (2000). Neuronal coding of prediction errors. Annu Rev Neurosci 23: 473-500.

Segal DS, Mandell AJ (1974). Long-term administration of D-amphetamine: progressive augmentation of motor activity and stereotypy. Pharmacol Biochem Behav 2: 249-255.

Sellings LH, Clarke PB (2003). Segregation of amphetamine reward and locomotor stimulation between nucleus accumbens medial shell and core. J Neurosci 23: 6295-6303.

Sesack SR (2009). Functional implications of dopamine D2 receptor localization in relation to glutamate neurons. In: Bjorklund A, Dunnett S, Iversen L, Iversen S (eds). Dopamine Handbook. Oxford University Press: New York.

Sesack SR, Carr DB (2002). Selective prefrontal cortex inputs to dopamine cells: implications for schizophrenia. Physiol Behav 77: 513-517.

Sesack SR, Deutch AY, Roth RH, Bunney BS (1989). Topographic organization of the efferent projections of the medial prefrontal cortex in the rat: an anterograde tract-tracing study using Phaseolus vulgaris leucoagglutinin. J Comp Neurol 290: 213-242.

Sesack SR, Pickel VM (1990). In the rat medial nucleus accumbens, hippocampal and catecholaminergic terminals converge on spiny neurons and are in apposition to each other. Brain Res 527: 266-279.

Sesack SR, Pickel VM (1992a). Dual ultrastructural localization of enkephalin and tyrosine hydroxylase immunoreactivity in the rat ventral tegmental area: multiple substrates for opiate-dopamine interactions. J Neurosci 12: 1335-1350. 
Sesack SR, Pickel VM (1992b). Prefrontal cortical efferents in the rat synapse on unlabeled neuronal targets of catecholamine terminals in the nucleus accumbens septi and on dopamine neurons in the ventral tegmental area. J Comp Neuro/ 320: 145-160. This paper was the first to demonstrate the synaptic integration of the PFC and VTA DA neurons, both at the level of the VTA and in the NAc.

Sharp PE (1999). Complimentary roles for hippocampal vs subicular/entorhinal place cells in coding place, context, and events. Hippocampus 9: 432-443.

Sidibé M, Smith Y (1999). Thalamic inputs to striatal interneurons in monkeys: synaptic organization and co-localization of calcium binding proteins. Neuroscience 89: 1189-1208.

Simmons DA, Neill DB (2009). Functional interaction between the basolateral amygdala and the nucleus accumbens underlies incentive motivation for food reward on a fixed ratio schedule. Neuroscience 159: 1264-1273.

Smith Y, Bennett BD, Bolam JP, Parent A, Sadikot AF (1994). Synaptic relationship between dopaminergic afferents and cortical or thalamic input in the sensorimotor territory of the striatum in monkey. J Comp Neurol 344: 1-19.

Smith Y, Bolam JP (1990). The output neurones and the dopaminergic neurones of the substantia nigra receive a GABA-containing input from the globus pallidus in the rat. J Comp Neurol 296: 47-64.

Smith Y, Charara A, Parent A (1996). Synaptic innervation of midbrain dopaminergic neurons by glutamate-enriched terminals in the squirrel monkey. J Comp Neurol 364: 231-253.

Smith Y, Kieval J, Couceyro P, Kuhar MJ (1999). CART peptide-immunoreactive neurons in the nucleus accumbens in monkeys: ultrastructural analysis, colocalization studies, and synaptic interactions with dopaminergic afferents. J Comp Neurol 407: 491-511.

Smith Y, Raju DV, Pare JF, Sidibe M (2004). The thalamostriatal system: a highly specific network of the basal ganglia circuitry. Trends Neurosci 27: 520-527.

Smith Y, Villalba R (2008). Striatal and extrastriatal dopamine in the basal ganglia: an overview of its anatomical organization in normal and Parkinsonian brains. Mov Disord 23: S534-S547.

Somogyi P, Bolam JP, Totterdell S, Smith AD (1981). Monosynaptic input from the nucleus accumbens-ventral striatum region to retrogradely labeled nigrostriatal neurones. Brain Res 217: 245-263.

Steffensen SC, Svingos AL, Pickel VM, Henriksen SJ (1998). Electrophysiological characterization of GABAergic neurons in the ventral tegmental area. J Neurosci 18: 8003-8015.

Surmeier DJ, Ding J, Day M, Wang Z, Shen W (2007). D1 and D2 dopaminereceptor modulation of striatal glutamatergic signaling in striatal medium spiny neurons. Trends Neurosci 30: 228-235.

Surmeier DJ, Eberwine J, Wilson CJ, Cao Y, Stefani A, Kitai ST (1992). Dopamine receptor subtypes colocalize in rat striatonigral neurons. Proc Natl Acad Sci 89: 10178-10182.

Surmeier DJ, Song W-J, Yan Z (1996). Coordinated expression of dopamine receptors in neostriatal medium spiny neurons. J Neurosci 16: 6579-6591.

Suto N, Tanabe LM, Austin JD, Creekmore E, Vezina P (2003). Previous exposure to VTA amphetamine enhances cocaine self-administration under a progressive ratio schedule in an NMDA, AMPA/kainate, and metabotropic glutamate receptor-dependent manner. Neuropsychopharmacology 28: 629-639.

Swanson LW (1982). The projections of the ventral tegmental area and adjacent regions: a combined fluorescent retrograde tracer and immunofluorescence study in the rat. Brain Res Bull 9: 321-353. This comprehensive analysis detailed the forebrain projections, DA component, and extent of collateralization of VTA neurons.

Swanson LW, Hartman BK (1975). The central adrenergic system. An immunofluorescence study of the location of cell bodies and their efferent connections in the rat utilizing dopamine-B-hydroxylase as a marker. J Comp Neurol 163: 467-487.

Swanson LW, Köhler C (1986). Anatomical evidence for direct projections from the entorhinal area to the entire cortical mantle in the rat. J Neurosci 6: 3010-3023.

Tagliaferro P, Morales M (2008). Synapses between corticotropin-releasing factorcontaining axon terminals and dopaminergic neurons in the ventral tegmental area are predominantly glutamatergic. J Comp Neurol 506: 616-626.

Taverna S, Canciani B, Pennartz CM (2007). Membrane properties and synaptic connectivity of fast-spiking interneurons in rat ventral striatum. Brain Res 1152: 49-56.

Taverna S, van Dongen YC, Groenewegen HJ, Pennartz CM (2004). Direct physiological evidence for synaptic connectivity between medium-sized spiny neurons in rat nucleus accumbens in situ. J Neurophysiol 91: 1111-1121.

Tepper JM, Wilson CJ, Koos T (2008). Feedforward and feedback inhibition in neostriatal GABAergic spiny neurons. Brain Res Rev 58: 272-281.

Thomas TM, Smith Y, Levey Al, Hersch SM (2000). Cortical inputs to m2-immunoreactive striatal interneurons in rat and monkey. Synapse 37: 252-261.

Totterdell S, Meredith GE (1997). Topographical organization of projections from the entorhinal cortex to the striatum of the rat. Neuroscience 78: 715-729.
Totterdell S, Smith AD (1989). Convergence of hippocampal and dopaminergic input onto identified neurons in the nucleus accumbens of the rat. $J$ Chem Neuroanat 2: 285-298. This paper provided the first anatomical evidence for synaptic convergence of cortical and DA axons onto common medium spiny neurons in the NAc.

Uchimura N, Higashi H, Nishi S (1986). Hyperpolarizing and depolarizing actions of dopamine via D-1 and D-2 receptors on nucleus accumbens neurons. Brain Res 375: 368-372.

Ungless MA, Magill PJ, Bolam JP (2004). Uniform inhibition of dopamine neurons in the ventral tegmental area by aversive stimuli. Science 303: 2040-2042.

Ungless MA, Whistler JL, Malenka RC, Bonci A (2001). Single cocaine exposure in vivo induces long-term potentiation in dopamine neurons. Nature 411 583-587. This paper showed that even single doses of cocaine can cause long-term alterations in responses of DA neurons.

Usuda I, Tanaka K, Chiba T (1998). Efferent projections of the nucleus accumbens in the rat with special reference to subdivision of the nucleus: biotinylated dextran amine study. Brain Res 797: 73-93.

Valenti O, Grace AA (2008). Acute and repeated stress induce a pronounced and sustained activation of VTA DA neuron population activity. Soc Neurosc Abstr: 479.11.

Van Bockstaele EJ, Cestari DM, Pickel VM (1994). Synaptic structure and connectivity of serotonin terminals in the ventral tegmental area: potential sites for modulation of mesolimbic dopamine neurons. Brain Res 647: 307-322.

Van Bockstaele EJ, Pickel VM (1993). Ultrastructure of serotonin-immunoreactive terminals in the core and shell of the rat nucleus accumbens: cellular substrates for interactions with catecholamine afferents. J Comp Neurol 334 603-617.

Van Bockstaele EJ, Pickel VM (1995). GABA-containing neurons in the ventral tegmental area project to the nucleus accumbens in rat brain. Brain Res 682: 215-221.

van Dongen YC, Mailly P, Thierry AM, Groenewegen HJ, Deniau JM (2008). Threedimensional organization of dendrites and local axon collaterals of shell and core medium-sized spiny projection neurons of the rat nucleus accumbens. Brain Struct Funct 213: 129-147

Vezina P, Giovino AA, Wise RA, Stewart J (1989). Environment-specific crosssensitization between the locomotor activating effects of morphine and amphetamine. Pharmacol Biochem Behav 32: 581-584.

Vezina P, Queen AL (2000). Induction of locomotor sensitization by amphetamine requires the activation of NMDA receptors in the rat ventral tegmental area Psychopharmacology 151: 184-191.

Voorn P, Gerfen CR, Groenewegen HJ (1989). Compartmental organization of the ventral striatum of the rat: immunohistochemical distribution of enkephalin, substance P, dopamine, and calcium-binding protein. J Comp Neurol 289 189-201.

Voorn P, Jorritsma-Byham B, Van Dijk C, Buijs R (1986). The dopaminergic innervation of the ventral striatum in the rat: a light- and electron-microscopical study with antibodies against dopamine. J Comp Neurol 251: 84-99. This was one of the first papers to characterize the light microscopic distribution and ultrastructural features of the DA input to the NAc in the rat.

Wanat MJ, Hopf FW, Stuber GD, Phillips PE, Bonci A (2008). Corticotropinreleasing factor increases mouse ventral tegmental area dopamine neuron firing through a protein kinase C-dependent enhancement of Ih. J Physiol 586: 2157-2170.

Wang HL, Morales M (2009). Pedunculopontine and laterodorsal tegmental nuclei contain distinct populations of cholinergic, glutamatergic and GABAergic neurons in the rat. Eur J Neurosci 29: 340-358.

Wang Z, Kai L, Day M, Ronesi J, Yin HH, Ding J et al (2006). Dopaminergic control of corticostriatal long-term synaptic depression in medium spiny neurons is mediated by cholinergic interneurons. Neuron 50: 443-452.

Waraczynski MA (2006). The central extended amygdala network as a proposed circuit underlying reward valuation. Neurosci Biobehav Rev 30: 472-496.

West AR, Galloway MP, Grace AA (2002). Regulation of striatal dopamine neurotransmission by nitric oxide: effector pathways and signaling mechanisms. Synapse 44: 227-245.

West AR, Grace AA (2002). Opposite influences of endogenous dopamine D1 and D2 receptor activation on activity states and electrophysiological properties of striatal neurons: studies combining in vivo intracellular recordings and reverse microdialysis. J Neurosci 22: 294-304. By using in vivo recordings, this paper showed how endogenous DA release affects the activity and excitability of striatal neurons via distinct receptor subclasses.

White FJ, Wang RY (1986). Electrophysiological evidence for the existence of both D-1 and D-2 dopamine receptors in the rat nucleus accumbens. J Neurosci 6: $274-280$.

Williams SM, Goldman-Rakic PS (1998). Widespread origin of the primate mesofrontal dopamine system. Cerebral Cortex 8: 321-345. 
Wilson CJ, Groves PM, Kitai ST, Linder JC (1983). Three-dimensional structure of dendritic spines in the rat neostriatum. J Neurosci 3: 383-398.

Wise RA (2004). Dopamine, learning and motivation. Nat Rev Neurosci 5: 483-494. Wise RA, Rompre PP (1989). Brain dopamine and reward. Annu Rev Psychol 40: 191-225.

Wolf ME (1998). The role of excitatory amino acids in behavioral sensitization to psychomotor stimulants. Prog Neurobiol 54: 679-720.

Wolf ME (2002). Addiction: making the connection between behavioral changes and neuronal plasticity in specific pathways. Mol Intervent 2: 146-157.

Wolf ME, Sun X, Mangiavacchi S, Chao SZ (2004). Psychomotor stimulants and neuronal plasticity. Neuropharmacology 47(Suppl 1): 61-79.

Wong DF, Kuwabara H, Schretlen DJ, Bonson KR, Zhou Y, Nandi A et al (2006). Increased occupancy of dopamine receptors in human striatum during cueelicited cocaine craving. Neuropsychopharmacology 31: 2716-2727.

Wright Cl, Beijer AV, Groenewegen HJ (1996). Basal amygdaloid complex afferents to the rat nucleus accumbens are compartmentally organized. J Neurosci 16: 1877-1893.

Wu M, Hrycyshyn AW, Brudzynski SM (1996). Subpallidal outputs to the nucleus accumbens and ventral tegmental area: anatomical and electrophysiological studies. Brain Res 740: 151-161.

Yamaguchi T, Sheen W, Morales M (2007). Glutamatergic neurons are present in the rat ventral tegmental area. Eur J Neurosci 25: 106-118. This definitive paper demonstrated a newly identified population of glutamate neurons in the VTA and quantified the extent to which they are colocalized with DA cells.

Yang CR, Mogenson GJ (1984). Electrophysiological responses of neurones in the nucleus accumbens to hippocampal stimulation and the attenuation of the excitatory responses by the mesolimbic dopaminergic system. Brain Res 324: 69-84.

Yao WD, Spealman RD, Zhang J (2008). Dopaminergic signaling in dendritic spines. Biochem Pharmacol 75: 2055-2069.

Yin HH, Ostlund SB, Balleine BW (2008). Reward-guided learning beyond dopamine in the nucleus accumbens: the integrative functions of cortico-basal ganglia networks. Eur J Neurosci 28: 1437-1448.
Zahm DS (1989). The ventral striatopallidal parts of the basal ganglia in the rat - II. Compartmentation of ventral pallidal afferents. Neuroscience 30: 33-50.

Zahm DS (1992). An electron microscopic morphometric comparison of tyrosine hydroxylase immunoreactive innervation in the neostriatum and the nucleus accumbens core and shell. Brain Res 575: 341-346.

Zahm DS (2000). An integrative neuroanatomical perspective on some subcortical substrates of adaptive responding with emphasis on the nucleus accumbens. Neurosci Biobehav Rev 24: 85-105.

Zahm DS (2006). The evolving theory of basal forebrain functional-anatomical 'macrosystems'. Neurosci Biobehav Rev 30: 148-172.

Zahm DS, Brog JS (1992). On the significance of subterritories in the 'accumbens' part of the rat ventral striatum. Neuroscience 50: 751-767. This decisive paper solidified years of work justifying the structural, functional, connectional, and neurochemical subdivision of the NAc into core, shell and rostral pole territories.

Zahm DS, Grosu S, Williams EA, Qin S, Bérod A (2001). Neurons of origin of the neurotensinergic plexus enmeshing the ventral tegmental area in rat: retrograde labeling and in situ hybridization combined. Neuroscience 104: 841-851.

Zahm DS, Heimer L (1990). Two transpallidal pathways originating in the rat nucleus accumbens. J Comp Neurol 302: 437-446.

Zahm DS, Heimer L (1993). Specificity in the efferent projections of the nucleus accumbens in the rat: comparison of the rostral pole projection patterns with those of core and shell. J Comp Neurol 327: 220-232.

Zahm DS, Williams E, Wohltmann C (1996). Ventral striatopallidothalamic projection: IV. Relative involvements of neurochemically distinct subterritories in the ventral pallidum and adjacent parts of the rostroventral forebrain. $J$ Comp Neurol 364: 340-362.

Zhang XF, Hu XT, White FJ, Wolf ME (1997). Increased responsiveness of ventral tegmental area dopamine neurons to glutamate after repeated administration of cocaine or amphetamine is transient and selectively involves AMPA receptors. J Pharmacol Exp Ther 281: 699-706.

Zweifel LS, Argilli E, Bonci A, Palmiter RD (2008). Role of NMDA receptors in dopamine neurons for plasticity and addictive behaviors. Neuron 59: 486-496. 